NATIONAL LABORATORY

MANAGED BY UT-BATTELLE

FOR THE DEPARTMENT OF ENERGY

\title{
Background Report on Eastern Democratic Republic of the Congo
}

\section{March 24, 2011}

\author{
Prepared by \\ Tracy Warren \\ Research Scientist
}

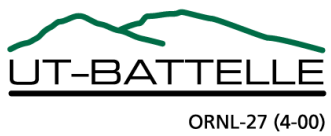




\title{
DOCUMENT AVAILABILITY
}

Reports produced after January 1, 1996, are generally available free via the U.S. Department of Energy (DOE) Information Bridge.

Web site http://www.osti.gov/bridge

Reports produced before January 1, 1996, may be purchased by members of the public from the following source.

\author{
National Technical Information Service \\ 5285 Port Royal Road \\ Springfield, VA 22161 \\ Telephone 703-605-6000 (1-800-553-6847) \\ TDD 703-487-4639 \\ Fax 703-605-6900 \\ E-mail info@ntis.gov \\ Web site http://www.ntis.gov/support/ordernowabout.htm
}

Reports are available to DOE employees, DOE contractors, Energy Technology Data Exchange (ETDE) representatives, and International Nuclear Information System (INIS) representatives from the following source.

Office of Scientific and Technical Information

P.O. Box 62

Oak Ridge, TN 37831

Telephone 865-576-8401

Fax 865-576-5728

E-mail reports@osti.gov

Web site http://www.osti.gov/contact.html

This report was prepared as an account of work sponsored by an agency of the United States Government. Neither the United States Government nor any agency thereof, nor any of their employees, makes any warranty, express or implied, or assumes any legal liability or responsibility for the accuracy, completeness, or usefulness of any information, apparatus, product, or process disclosed, or represents that its use would not infringe privately owned rights. Reference herein to any specific commercial product, process, or service by trade name, trademark, manufacturer, or otherwise, does not necessarily constitute or imply its endorsement, recommendation, or favoring by the United States Government or any agency thereof. The views and opinions of authors expressed herein do not necessarily state or reflect those of the United States Government or any agency thereof. 


\title{
BACKGROUND REPORT ON EASTERN DEMOCRATIC REPUBLIC OF THE CONGO
}

\author{
Tracy Warren
}

Date Published: March 2011

Prepared by

OAK RIDGE NATIONAL LABORATORY

Oak Ridge, Tennessee 37831-6283

managed by

UT-BATTELLE, LLC

for the

U.S. DEPARTMENT OF ENERGY

under contract DE-AC05-00OR22725 



\section{CONTENTS}

\section{Page}

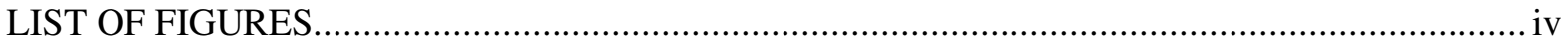

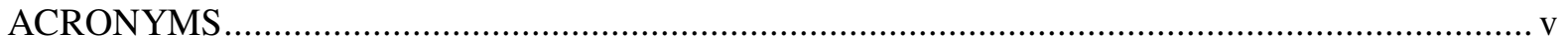

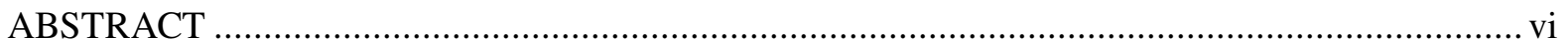

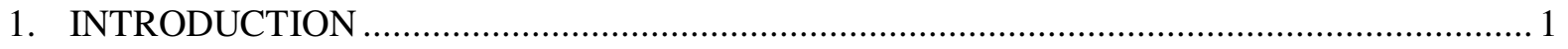

2. INTRODUCTION TO HISTORY OF CONFLICT AND EXPLOITATION …..................... 2

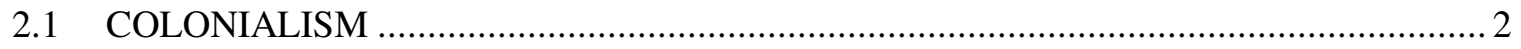

2.2 INDEPENDENCE AND THE FIRST REPUBLIC, 1960-1965 ................................. 2

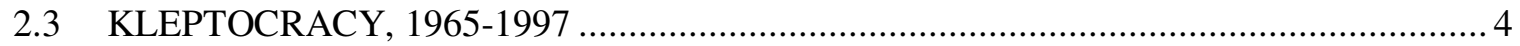

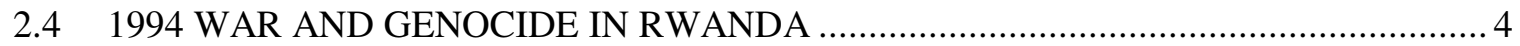

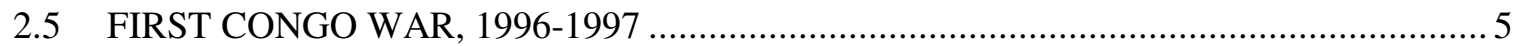

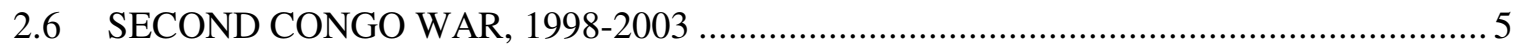

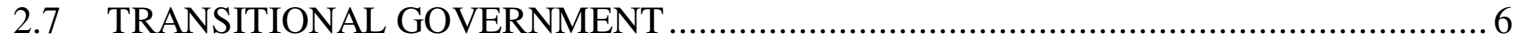

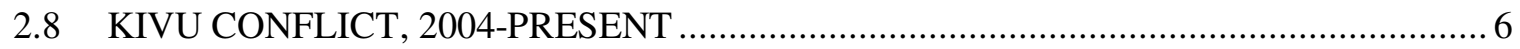

3. SOCIAL AND ECONOMIC CAUSES OF CONFLICT IN EASTERN DRC .......................... 11

3.1 NATURAL RESOURCES IN EASTERN DRC …............................................ 15

4. SUPPLY CHAIN FOR CONFLICT MINERALS ORIGINATING FROM EASTERN

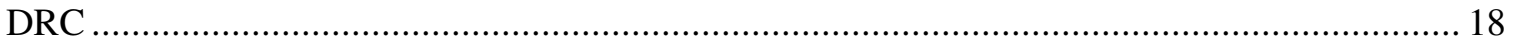

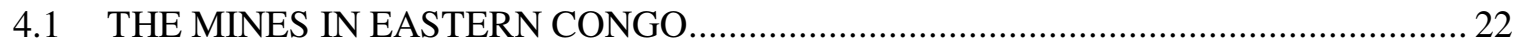

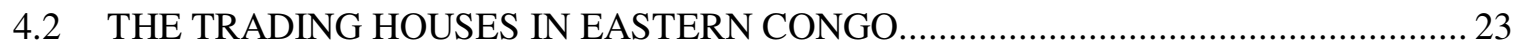

4.3 THE EXPORTERS IN EASTERN CONGO .............................................................. 24

4.4 THE TRANSIT COUNTRIES, RWANDA/UGANDA/KENYA ................................... 25

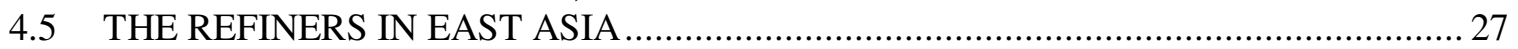

4.6 THE ELECTRONIC COMPANIES IN EAST ASIA/EUROPE .................................... 27

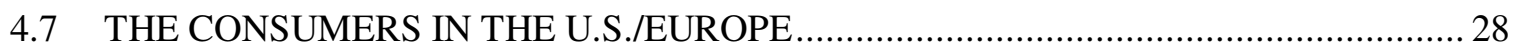

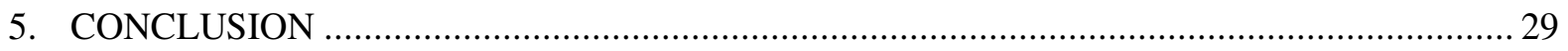

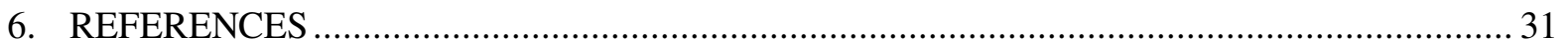

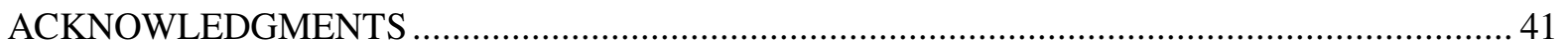

Appendix A: DEMOCRATIC REPUBLIC OF THE CONGO FACTS …................................ A-1

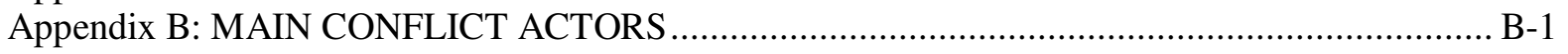




\section{LIST OF FIGURES}

Figure

Page

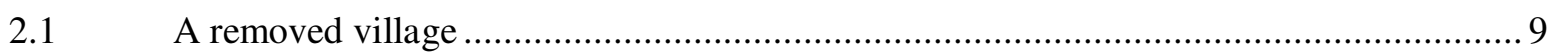

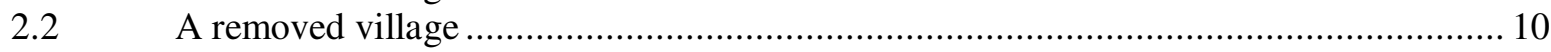

3.1 Topographic map of Democratic Republic of the Congo ........................................ 15

3.2 Democratic Republic of the Congo mineral resources map........................................ 16

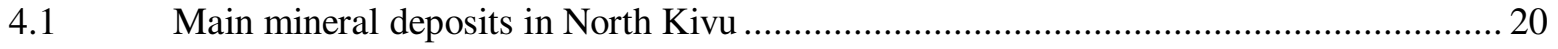

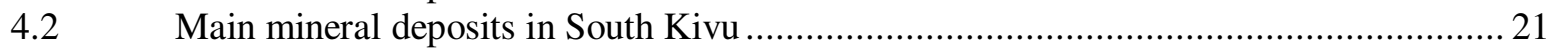

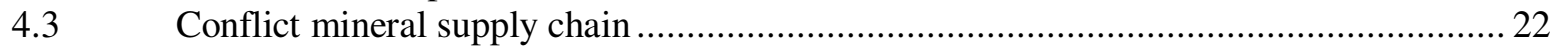

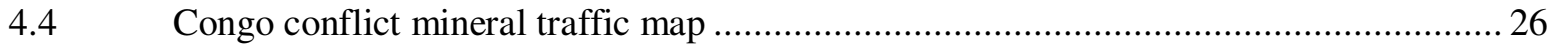

4.5 Flow diagram of Congo's conflict mineral supply chain........................................... 28 


\section{ACRONYMS}

$\begin{array}{ll}\text { AAAS } & \text { American Association for the Advancement of Science } \\ \text { ABAKO } & \text { Alliance des Bakongo } \\ \text { AFDL } & \text { Alliance des Forces Démocratiques pour la Libération du Congo-Zaire } \\ \text { AFRICOM } & \text { United States African Command } \\ \text { CAR } & \text { Central African Republic } \\ \text { CIA } & \text { Central Intelligence Agency } \\ \text { CNDP } & \text { National Congress for the Defense of the People } \\ \text { CNS } & \text { Conférence Nationale Souveraine } \\ \text { DRC } & \text { Democratic Republic of the Congo } \\ \text { FARDC } & \text { Forces Armées de la République Démocratique du Congo } \\ \text { FDLR } & \text { Democratic Forces for the Liberation of Rwanda } \\ \text { FEC } & \text { Fédération des Entereprises du Congo } \\ \text { FNL } & \text { Forces for National Liberation } \\ \text { FP } & \text { Force Publique } \\ \text { ICC } & \text { International Criminal Courts } \\ \text { IDP } & \text { Internally Displaced Person } \\ \text { IRC } & \text { International Rescue Committee } \\ \text { IMF } & \text { International Monetary Fund } \\ \text { ITRI } & \text { International Tin Research Institute } \\ \text { MLC } & \text { Mouvement pour la Libération du Congo } \\ \text { MONUC } & \text { United Nations Organization Mission in the DRC } \\ \text { PARECO } & \text { Coalition of Patriots in the Congolese Resistance } \\ \text { PCE } & \text { Primary Commodity Export } \\ \text { RCD } & \text { Rassemblement Congolais pour la Démocratie } \\ \text { ROC } & \text { Republic of Congo } \\ \text { RPF } & \text { Rwandan Patriotic Front } \\ \text { UN } & \text { United Nations } \\ \text { UNDP } & \text { Ugandan People's Defence Forces } \\ \text { UNOCHA } & \text { UN Office for the Coordination of Humanitarian Affairs }\end{array}$




\begin{abstract}
Each month, approximately 45,000 people die from violence, hunger, disease, and other effects of displacement as a result of war in the Democratic Republic of the Congo (DRC). The country is often said to be plagued by a "resource curse." During each period in history since its discovery by the West, the DRC has possessed the resources the world craves and the world has sought these without regard for the consequences to the Congolese people. The catastrophic consequences of Congo's history of natural resource exploitation are the direct and indirect death of millions of Congolese people. The current war in Congo is multi-causal in nature but explanations are often reduced to describing it as an ethic conflict based on objective grievance. Objective grievance such as inequality, ethnic tensions, land disputes, and lack of democracy do exist, but they are neither necessary nor sufficient to explain the cause of the violent conflict, and more importantly, they fall short in explaining why this conflict has continued for years. The reality is the conflict is an economic war in which the trade of conflict minerals, gold and the 3Ts (tin, tantalum, tungsten), is directly linked to the financial sustainability of the groups fighting each other in eastern DRC. Objective grievance is a by-product of the conflict, used to create a false but plausible moral justification to continue violence. This paper examines the history of conflict in the DRC and the socio-economic variables contributing to the current war fought over conflict minerals.
\end{abstract}




\section{INTRODUCTION}

Smartphones, laptops, digital cameras-ubiquitous symbols of modernity in Western society. But inside these sleek electronic gadgets are minerals that fuel a war that has left at least 5.4 million people dead since 1998 and labeled the Democratic Republic of the Congo (DRC) as the "rape capital of the world." This is an economic war in which the trade of conflict minerals, gold and the 3Ts (tin, tantalum, tungsten), is directly linked to the sustainability of the groups fighting each other in eastern DRC. Violent conflict in the eastern provinces of the DRC has physically, emotionally and financially devastated the people of the region. The war is fought between militias who have no ideology and no popular support. The militias commit horrific crimes against the people they are supposedly fighting for in order to terrorize and control them. North and South Kivu provinces of the DRC have been transformed into a massive crime scene, the site of unthinkable sexual violence against women, ethnic cleansing, torture, forced labor, and even forced cannibalism. Each month, approximately 45,000 people die from violence, hunger, disease, and other effects of displacement as a result of this war.

Congo is often said to be plagued by the "resource curse." During each period in history since its discovery by the West, the DRC has possessed the resources the world craves and the world has sought these without regard for the consequences to the Congolese people. This is a country that has been pillaged for the past 500 years. The first resource stolen from Congo was the Congolese themselves, for slavery in Brazilian mines and American cotton plantations. Under the Congo Free State the country was forced to effectively finance its own occupation to personally enrich King Leopold II as he stole its rubber and ivory. After the Belgian government took control of the colony, the mining of copper, diamonds and other minerals generated profits for shareholders in Belgium and elsewhere. Independence did not thwart the theft of Congo's resources. Under Mobutu's 32 year reign an estimated $\$ 5$ billion of the country's wealth was transferred overseas. In the Kabila years, neighboring countries have occupied Congolese territory trading defense of Congo with unfettered resource extraction. "Much as in Free State days, the Congo was financing the occupation of a portion of its own territory. Unlike Free State days, none of the proceeds of this pillage was being reinvested. In some cases it has fuelled ongoing fighting."1 The catastrophic consequences of Congo's history of natural resource exploitation are the direct and indirect death of millions of Congolese people.

The war in Congo is multi-causal in nature but explanations are often reduced to describing it as an ethic conflict based on objective grievance. While traditional ethnicity is important to the way people in the DRC identify themselves, it is superseded by new identities forged out of decades of oppression and poverty experience by most Congolese. ${ }^{2}$ Objective grievance such as inequality, ethnic tensions, land disputes, and lack of democracy do exist, but they are neither necessary nor sufficient to explain the cause of the violent conflict, and more importantly, they fall short in explaining why this conflict has continued for years. The reality is the conflict is an economic war driven by a complex mixture of actors including ethnic groups, militias, foreign armies, the Congolese army, foreign governments, multi-national companies, diaspora, and others who participate in the continuation of the conflict because each benefits financially from the exploitation of DRCs natural resources. Financial viability of conflict actors is of central importance to the prolonged crisis. Objective grievance is a by-product of the conflict, used to create a false but plausible moral justification to continue violence.

This paper is organized as follows:

Section 1 provides an introduction to the history of the conflict in the eastern DRC. Section 2 examines the social and economic causes of the conflict in eastern DRC.

Section 3 examines the supply chain for conflict minerals that originate from eastern DRC.

Section 4 concludes the background report. 


\section{INTRODUCTION TO HISTORY OF CONFLICT AND EXPLOITATION}

\subsection{COLONIALISM}

The pattern of exploitation of natural resources for possessions, accompanied by mass torture, rape, and killing, [and cloaked in moral justifications] by foreigners was sown soon after Congo was first discovered in 1482 by the Portuguese navigator, Diego Cão. Human slaves were the first commodity exported from Congo on a massive scale by Europeans. The Kingdom of Kongo became a center for the Atlantic slave trade by British, Dutch, Portuguese, and French merchants. The number of slaves shipped across the Atlantic to Brazil and the American South tripled from 5000 slaves a year in the 1530 s to 15,000 slaves a year during the $17^{\text {th }}$ century. ${ }^{3}$

During the late $19^{\text {th }}$ century raw materials needed to supply the Industrial Revolution drove further exploitation of Congo. In what became known as the Scramble for Africa, European countries vied with each other to carve Africa into colonies. By this time, the abolitionist movement had swept across Europe. Anti-slavery sentiments were strong. Europeans justified colonialism in Africa with calls to smash the "Arab" slave trade. Europeans also believed they had a God-given mission to spread the Christian gospel to the heathens and civilize the savage races in Africa. In the late 1800s, Belgium's King Leopold II tapped into Europeans new found sense of humanitarianism as he sought to acquire a colony of his own for personal enrichment. As he focused on the territory that was known as the Kingdom of Kongo, Leopold spoke of curbing the slave trade, bringing everyone benefits of free trade, and the advancement of science. At the Conference of Berlin in 1885, Leopold successfully negotiated the rights to the Congo from Britain, Germany, France, Portugal, and Italy. Leopold made the land his private property and named it the Congo Free State, the world's only colony claimed by one man. ${ }^{4}$

Leopold began a number of ambitious infrastructure projects to maximize the extraction of resource derived capital from the land, including the construction of a railway that ran from the coast to the capitol, Leopoldville (now Kinshasa). Leopold initially set out to loot the Congo Free State of ivory, but an even more valuable commodity would contribute to creating his vast personal fortune as well as that of many European companies. The spread of bicycles and automobiles around the world created a growing international market for tires made from rubber. Rubber prices quadrupled between the late 1880s and the early 1910s in the world market. Africa, led by Congo, supplied nearly half of the world's rubber production. To acquire wild rubber, Leopold implemented a system of rubber quotas, taxation, and forced labor brutally enforced by Leopold's army, Force Publique (FP), by cutting of the limbs of anyone who failed to comply or tried to fight back. But hostage taking was the preferred method of forced labor. Soldiers would arrive in a village, attack the villagers, and seize the women until the chief could bring in the required quotas of rubber. The women were repeatedly raped until the rubber was collected and then they were sold back to their families. Whole villages were wiped out and the hands of villagers became a sort of currency among FP soldiers. ${ }^{5}$ Leopold's brutal practices caused the death of as many as ten million Congolese between 1885 and 1908, cutting the population at least in half. The atrocities led to the first great international human rights movement of the twentieth century. The international outcry over the killings and atrocities caused the Belgian state to annex the Congo Free State from Leopold in 1908. Renamed Belgian Congo, the territory remained a colony for more than fifty years.

\subsection{INDEPENDENCE AND THE FIRST REPUBLIC, 1960-1965}

Demand for self-rule spread across Africa in the 1950s. A nationalist movement rose up in Belgian Congo and mass demonstrations and national riots occurred in Leopoldville in 1959. In May 1960 the first democratic parliamentary elections were held producing Patrice Lumumba, of the leftist Mouvement National Congolese, as prime minister and Joseph Kasavubu, of the Alliance des 
Bakongo (ABAKO) party, as president. (The elections would turn out to be the last free elections for another 35 years.) The Belgian FP tried to suppress the unrest, often brutally, but growing pressure led Belgium to grant Congo independence on June 30, 1960. The events that followed Congo's independence illustrate the nature of Western intervention and responsibility for Congo's unrest and its troubled governance. ${ }^{6}$

Several destabilizing events and forces led to crisis within the first few months of independence. First, the Congolese army, led by chief of staff Joseph Désiré Mobutu, mutinied. This was followed by the succession of Katanga Province, governed by Moise Tshombe, and South Kasai province. Belgium sent in troops to protect Belgian citizens and its copper and diamond mining interests in the region. United Nations (UN) peacekeepers were also sent in to help restore order, but they had no authority to intervene in internal affairs. In September 1960, President Kasavubu staged an army coup and dismissed Prime Minister Lumumba. A "constitutional" crisis ensued between the two leaders. Lumumba was a charismatic leader with a contagious message that Belgian, British, and American companies, heavily invested in Congo, were alarmed to hear: economic independence from Europe. Lumumba espoused a leftist ideology speaking of land reform and social programs, and asked the Soviet Union for help, all of which struck fear of "communism" into western governments. Two months after his election, the U.S. Central Intelligence Agency (CIA) authorized his assassination. However, Lumumba proved hard to get close to, so the CIA, along with Belgian authorities, financially supported anti-Lumumba elements within the Congo government, namely Joseph Désiré Mobutu, to get the job done. Lumumba was arrested, beaten, and finally, in January 1961, he was shot in Elizabethville and disposed of in the truck of a CIA agent's car. A UN commission determined Lumumba was killed by a Belgian mercenary in the presence of the newly appointed president, Tshombe.

The Congolese were ill-prepared to govern following independence. During the Belgian colonial era, the Congolese were ruled under a paternalistic political system, Bula Matari, similar to the apartheid system implemented in South Africa. ${ }^{7}$ Important political decisions were made from the royal palace and colonial offices in Brussels. As Europeans exited the country, they took with them their experience to run a functioning society. The Congolese lacked even basic military, administrative, and business experience to run their country, setting the Congo up for decades of chaos. When independence was granted by Belgium, there were fewer than thirty African university graduates in the entire territory. There were no Congolese army officers, engineers, lawyers, judges, agronomists, or physicians. Within the colonial administration, not a single Congolese administrator was qualified to oversee the complex operations put in place by the Belgians. Table 2.1 displays the ranks of African and European civil servants in June 1960. The new government experienced difficulty filling key positions in the administration and had to rely on Belgian personnel for high level civil service, university, hospital, and army positions for many years. ${ }^{8}$ 
Table 2.1. African and European civil servants in June $1960^{a}$

\begin{tabular}{c|c|c}
\hline Ranks & Europeans & Africans \\
\hline High-ranking functionaries & 5,900 & 0 \\
Mid-level functionaries & & 9 \\
Office managers & 1,690 & 24 \\
Assistant managers & 1,976 & 726 \\
Clerks & 774 & 10,791 \\
Low-level functionaries & 0 & 11,550 \\
\hline Total & 10,340 & \\
\hline
\end{tabular}

${ }^{a}$ Source: Ch. Didier Gondola, The History of Congo, (Westport, CT: Greenwood Press, 2002), 116.

\subsection{KLEPTOCRACY, 1965-1997}

Civil unrest and rebellion continued in Congo until 1965 when Joseph Désiré Mobutu, now a lieutenant general and commander-in-chief of the national army, seized power from Kasavubu, ushering in the era of kleptocracy that lasted 32 years. Mobutu established a one-party system, centralized power, and promoted cronyism, nepotism and corruption in all sectors of society. ${ }^{9}$ In 1971 he instituted a program of African cultural awareness in which citizens were required to adopt African names; he changed his name to Mobutu Sese Seko and Congo's name to Zaire. Mobutu received support from western governments supporting realpolitik, including over a billion dollars from the United States in military and civilian aid during his rule, because he was a staunch opponent of communism. U.S. military aid helped Mobutu repel several attempts to overthrow him. Mobutu's foreign supporters claimed that without his authoritarian rule, Congo would plunge into chaos and civil war because of underlying ethnic tensions. However, Mobutu and his entourage were so corrupt that the Congolese government ceased to function and the state experienced unprecedented economic deterioration. ${ }^{10}$ Mobutu allowed Zaire's natural resources to flow freely out of Zaire without any regulation and he embezzled huge sums of money from the country with conservative estimates placing the figure at $\$ 5$ billion by 1984. Mobutu also brutalized the Congolese, maintaining his position through military force to stifle internal opposition. ${ }^{11}$ As the Cold War began to wind down, Mobutu's relevance to the U.S. cooled and aid began to dwindle. In 1993 he ran out of money to pay the army and other state workers and he resorted to printing up a new kind of currency. Shopkeepers refused the currency and soldiers rioted over unpaid wages. Hundreds of people were killed. Over the next several years, conditions in Zaire deteriorated and internal and external opponents stepped up demands for reform. Mobutu was forced to declare an end of single-party rule in April 1990 at the Conférence Nationale Souveraine (CNS) laying the foundation for the transition to a multiparty democracy and his eventual demise. ${ }^{12}$

\subsection{WAR AND GENOCIDE IN RWANDA}

The assassination of Rwandan President Habyarimana by Hutu extremists on April 6, 1994 plunged Rwanda into a war and the genocide of one million Tutsi and moderate Hutu people. The Hutu majority organized and implemented the mass killing of the Tutsi minority and Hutu political moderates by two Hutu militias, the Interahamwe and the Impuazmugambi. The Tutsi Rwandan Patriotic Front (RPF) eventually defeated the Hutu militias and took control of the country. In the aftermath of the genocide nearly two million Hutus, both participants and bystanders in the genocide, fled from Rwanda in anticipation of Tutsi retaliation. The majority fled to eastern Zaire where Mobutu provided shelter and protection to the refugees, including to the Rwandan Hutu forces that directed the genocide. The militias were still heavily armed and used the UN refugee camps as bases for cross- border incursions against the new Tutsi-led government of Rwanda. The Hutus took refuge in an area where a large population of indigenous ethnic Tutsi, known as Banyamulenge, resided. 
Under Mobutu's regime the Banyamulenge were stripped of their Zairean citizenship and were targets of ethnic violence by the government forces. With the influx of Rwandan Hutus, ethnic tensions flared and the instability that resulted ultimately helped force Mobutu from power. ${ }^{13}$

\subsection{FIRST CONGO WAR, 1996-1997}

By 1996, Hutu-led incursions into Rwanda prompted a foreign military coalition of Rwandan and Ugandan troops to invade Zaire under the cover of a small group of Tutsi militia to fight the Hutu militias. A little known, but long-standing guerilla movement led by Laurent Désire Kabila, a former warlord, saw an opportunity to form a coalition with Rwandan and Ugandan armies, the Alliance des Forces Démocratiques pour la Libération du Congo-Zaire (AFDL), and launch a seven month campaign to oust Mobutu. In May 1997, Mobutu fled Zaire following failed peace talks with Kabila, the AFDL marched to Kinshasa and Kabila declared himself president. Kabila consolidated power around himself and the Rwandan-influenced AFDL. The country was renamed the Democratic Republic of the Congo. However, fighting Hutu militia forces does not appear to have been the only motivating factor for foreign government involvement. There is evidence that Laurent Désire Kabila promised presidents Paul Kagame of Rwanda and Yoweri Museveni of Uganda access to Congo's profitable mineral resources when forming his coalition. From the outset of the rebellion a complex network of foreign mining companies, administrative appointees, trucking and airline companies, and financial institutions located in Kigali, Kampala, and New York to drained off Congo's resources in occupied zones. ${ }^{14}$ The UN Panel of Experts on the illegal exploitation of natural resource in the DRC concluded that between September 1998 and August 1999:

Regardless of the looter, the pattern was the same: Burundian, Rwanda, Uganda and/or RCD soldiers, commanded by an officer, visited farms, storage facilities, factories and banks, and demanded that the managers open the coffers and doors. The soldiers were then ordered to remove the relevant products and load them into vehicles. ${ }^{15}$

\subsection{SECOND CONGO WAR, 1998-2003}

The Congolese were hopeful that Laurent Désire Kabila would implement substantial social and economic reforms; however, conditions in Congo did not improve. Kabila's autocratic style surfaced quickly and human rights abuses became a trademark of Kabila's regime including targeted attacks on Hutu refugees who had fled Rwanda. Kabila's popularity among the population quickly declined. Tensions between Kabila and his foreign backers also emerged as their political and financial arrangements fell apart. In an attempt to gain independence from Rwanda and Uganda, Kabila ordered all foreign troops to leave DRC in July 1998, but most refused. Nationwide fighting erupted on August 2, 1998 when Congolese rebel forces, backed by Rwandan and Ugandan troops, launched a new Tutsi-led rebel movement called the Rassemblement Congolais pour la Démocratie (Congolese Democratic Rally-RCD) that began a march to Kinshasa to replace Kabila. Troops from Angola, Chad, Sudan, Zimbabwe and Namibia successfully intervened on behalf of Kabila. The Rwandans and RCD retreated to the east where they effectively controlled portions of eastern DRC and continued to fight the Congolese army and its foreign allies. A parallel rebel movement was started by Ugandan troops in February 1999, the Mouvement pour la Libération du Congo (MLC), which drew support from among ex-Mobutuists and ex-Zairian soldiers in Equateur province (Mobutu's home province). Together, Uganda and the MLC established control over the northern third of the DRC. At this point, DRC was divided into three de facto segments controlled by Laurent Désire Kabila, the Rwandan RCD, and the Ugandan MLC. In August 1999, the Lusaka Accord was signed by all parties calling for a cease-fire, the deployment of a UN peacekeeping operation, the withdrawal 
of foreign troops, and the launching of an "Inter-Congolese Dialogue" to form a transitional government leading to elections. Provisions of Accord were not fully met in 1999 or 2000 by the parties and Kabila blocked full deployment of UN troops.

On January 16, 2001, Laurent Désire Kabila was assassinated by one of his body guards. His son, Joseph Kabila, was named head of state. Joseph Kabila demonstrated a willingness to enter peace talks and end the war. Joseph Kabila allowed full deployment of UN peacekeeping troops, named United Nations Organization Mission in the DRC (MONUC), throughout DRC. In July 2002, negotiations between Joseph Kabila and Rwandan President Paul Kagame in South Africa culminated in the Pretoria Accord, a peace deal under which Rwanda agreed to withdraw its troops from eastern DRC. In September 2002, Joseph Kabila successfully negotiated the withdrawal of Uganda forces occupying DRC. Rwanda and Uganda claimed to have withdrawn most of their forces from eastern DRC in October 2002 and UN-sponsored power-sharing talks began in South Africa followed by the signing of the Pretoria Accord by all remaining warring parties to end fighting and establish a government of national unity in December 2002.

\subsection{TRANSITIONAL GOVERNMENT}

A transitional government was set up in July 2003 with Joseph Kabila as president and four vice presidents to represent the former government, former rebel groups, the political opposition, and civil society. A successful constitutional referendum was held in December 2005 and on February 16, 2006 the Constitution was adopted. The first democratic presidential and parliamentary elections since Congo's independence from Belgium were held in July 2006 with a run-off held in October between Joseph Kabila and Jean Pierre Bemba after no clear winner emerge for president. Joseph Kabila was declared the winner of the run-off election and inaugurated in December 2006. Kabila has made progress in liberalizing domestic political activity and undertaken economic reforms in cooperation with the World Bank and International Monetary Fund (IMF). ${ }^{16}$

\subsection{KIVU CONFLICT, 2004-PRESENT}

The Congolese government remains weak and ineffective, unable to provide basic security and justice to the people of eastern DRC. Congolese and foreign militias and the Congolese army have continued to operate with impunity in eastern DRC. The Democratic Forces for the Liberation of Rwanda (FDLR) and National Congress for the Defense of the People (CNDP) have fought each other and Forces Armées de la République Démocratique du Congo (FARDC), the Congolese army (see Appendix B for conflict actors). FDLR, CNDP, and FARDC illegally exploit and export natural resources to fund weapons. All sides involved in the fighting continue to commit gross human rights violations and use sexual violence as a weapon of war against civilians to terrorize, control and ethnically cleanse targeted populations.

In 2004, Laurent Nkunda's CNDP forces began clashing with the DRC army, occupying Bukavu by May 2004. UN negotiations led CNDP to withdraw from the area but Nkunda's troops again clashed with the FARDC and with MONUC peacekeepers beginning in January 2006. In an effort to reduce Nkunda's power, the Congolese government tried to integrate CNDP troops into the FARDC. However, the effort backfired and Nkunda effectively controlled five army brigades between January and August 2007. Following battles with FARDC in August 2007, Nkunda requested a return to peace negotiations. Nkunda, however, missed an October 15, 2007 deadline for his troops to begin disarming and the fighting between CNDP and FARDC intensified. A peace deal, the Goma Accords, was finally signed on January 23, 2008 by Nkunda and over 20 other armed groups with provisions for an immediate ceasefire, the phased withdrawal of all rebel forces in North Kivu, the resettlement of thousands of villagers who fled during the fighting, and immunity for Nkunda's forces, improved adherence to human rights standards, and the deployment of UN peacekeepers in 13 key areas. ${ }^{17}$ Between January and August 2008, most of the parties worked to implement the Goma 
Accords' provisions, although there were regular cease-fire violations. In late August 2008, intense fighting began again between the CNDP and the FARDC in the southern part of North Kivu province. Over the next four months, this fighting resulted in the internal displacement of a 250,000 residents of North Kivu and led some 40,000 to flee into Uganda. Hundreds of people were killed. By late October 2008, Nkunda's CNDP forces, now much stronger and better disciplined than the Congolese military, got to within a few miles of Goma before declaring a unilateral cease-fire.

In January 2009, infighting in CNDP leadership led to a schism in which Nkunda's military chief of staff staged a de facto internal coup and then signed an agreement with DRC to integrate his forces into the FARDC. The rebel group Coalition of Patriots in the Congolese Resistance (PARECO) made a similar commitment to FARDC integration. Also in January 2009, the Congolese and Rwandan governments announced plans for Rwandan forces to enter eastern DRC and join with the Congolese military in a joint effort to eliminate the FDLR. On January 20, 2009, for the third time in 12 years, several thousand Rwandan soldiers crossed into DRC. Laurent Nkunda fled to Rwanda on January 22, 2009, where he was placed under house arrest. Between January 20 and February 25, 2009, Umoja Wetu, the joint Rwandan-Congolese operation in North Kivu, fought to dismantle FDLR's military capacity and convinced several hundred FDLR members and their families to return to Rwanda. FDLR was initially pushed away from military bases in North Kivu. However, FDLR was able to re-occupy some positions and conducted frequent reprisal campaigns against civilians, killing, raping, looting and burning villages, and caused the displacement of thousands. ${ }^{18}$ Rwandan forces left eastern DRC on February 25, 2009. On March 23, 2009, DRC signed separate peace agreements with armed groups who agreed to transform their movements from military to political in nature. The Congolese government promised to integrate rebel soldiers and officials into the FARDC, national police, and national and local political and administrative units. ${ }^{19}$ The FARDC, with support from MONUC, offered ex-combatants the opportunity to undergo "accelerated integration" into the national army, a process that was less thorough than traditional integration but allowed for more expeditious demobilization of rebel forces. ${ }^{20}$

The FARDC, with MONUC support, launched Operation Kimia II, a military operation against the FDLR in North and South Kivu in May 2009 and July 2009, respectively. Kimia II, which ended on December 31, 2009, registered some noticeable success, including pushing the bulk of the FDLR away from population centers and money-making enterprises, notably illegal mining. ${ }^{21}$ According to MONUC, in 2009 (roughly the same time period as Kimia II), FDLR forces were reduced by half, from approximately 6,000 to an estimated 3,200 (ref. 22), and 1,378 ex-FDLR combatants and 1,940 of their dependents were voluntarily disarmed and repatriated to Rwanda. ${ }^{23}$ However, Kimia II exacerbated the humanitarian crisis in the Kivus. Human rights violations by the FDLR and by undisciplined FARDC elements increased and the operation resulted in the expansion of CNDPs military influence in the region. ${ }^{24}$ MONUC estimated that as many as 1,714 civilians were killed during the military operation. ${ }^{25}$ The UN Groups of Experts was highly critical of the Kimia II operation in its November 2009 report to the UN Security Council. A number of the Group's findings are important to highlight:

- Recent military operations against FDLR have failed to dismantle the organization's political and military structures in eastern DRC. FDLR combatant defection is only partially successful and the remaining combatants have regrouped in a number of locations in the Kivus and continue to recruit. ${ }^{26}$

- The FDLR continues to benefit from residual but significant support from top commanders of FARDC, particularly those in the $10^{\text {th }}$ military region of South Kivu. There is a continued pattern of diversion of arms and ammunition that benefit non-State armed groups, including FDLR, with FARDC one of the principal sources of arms and ammunitions. ${ }^{27}$

- The FDLR has sealed strategic alliances with other regional armed groups in North and South Kivu. Networks among the FDLR, Mai Mai, and Forces for National Liberation (FNL) have formed an alliance and collaborate tightly with each other. They cooperate 
in smuggling natural resources, share weapons stocks and assist each other to infiltrate and hide out in the Ruzizi plain and across the border in forested areas of Burundi. ${ }^{28}$

- External support networks have been used to counteract effects of Kimia II. Burundi is being used as a rear base for FDLR recruitment and support networks. ${ }^{29}$

- A far reaching diaspora network is involved in the day-to-day running of the FDLR activities, coordination of military and arms trafficking, and management of finances. FDLR and RUD-Urunana diaspora networks in Europe, North America, and wider African regions have continued to operate and have been deeply involved in managing the response to FARDC. Support by diaspora is provided through fund-raising and propaganda exercises and money-laundering activities. Without this external support, FDLR's and the Rally for Unity and Democracy's (RUD-Urunana) operations on the ground in the DRC would be significantly disrupted. ${ }^{30}$

- The continued exploitation of gold and cassiterite reserves in the Kivus provides millions of dollars in direct financing for the FDLR. ${ }^{31}$

- Significant problems associated with the integration of non-State armed groups into FARDC remain. In January 2009 an estimated 12,000 combatants from CNDP, PARECO, and other Mai Mai groups participated in a rapid integration exercise and were incorporated into FARDC ranks. However, delays in payments of salaries led to waves of desertions from FARDC ranks during early 2009, particularly elements from Mai Mai Asani and Hutu in CNDP. In North and South Kivu FARDC commanding officers on the ground are former CNDP officers. The officer class of CNDP continues to retain heavy weapons acquired during its period of rebellion and still controls revenue-generating activities and parallel local administrations. CNDP troops deployed as part of FARDC Kimia II operations have profited from their deployment in mineral-rich areas. Children recruited by armed groups were integrated into FARDC..$^{32}$ The UN has noted a series of deliberate interference by certain FARDC units in MONUC's attempts to demobilize and repatriate large numbers of FDLR troops and dependents. ${ }^{33}$

- FARDC and FDLR are involved in significant killings of civilian and other abuses causing additional waves of displacement of several hundred thousand civilians. ${ }^{34}$

A follow-on operation, Amani Leo, was launched by the FARDC and MONUC in January 2010 to replace Kimia II. It appears that Amani Leo will be more selective in its targets, as well as concentrating on holding re-captured territory and developing state institutions and authority in these areas. $^{35}$ The priority of the Amani Leo operation is civilian protection, especially of children and women. ${ }^{36}$

The human cost of military operations has been devastating. This is the world's most deadly crisis since WWII. According to the International Rescue Committee (IRC) an estimated 5.4 million people have died since 1998 due to the consequences of the wars, namely the collapse of the health care system and economy. Approximately 500,000 people die each year; that is 45,000 deaths per month. During the most recent survey in 2007, the IRC found that only $0.4 \%$ of excess deaths were the direct result of violence. Most deaths are due to preventable and curable conditions, such as malaria, diarrhea, pneumonia, malnutrition, and neonatal problems. Children account for nearly $50 \%$ of recorded deaths, despite constituting $19 \%$ of the population. Mortality rates in DRC are nearly $60 \%$ higher than average for sub-Saharan Africa. ${ }^{37}$

The Congo is often described as the world's worst place to be a woman or a girl. More than 7,500 women and girls were raped in the first half of 2009 in the eastern regions of North and South Kivu, double the rate from the same period in 2008 (ref. 38). Some 200,000 cases of rape have been recorded since 1996 (ref. 39) but the UN High Commissioner for Refugees (UNHCR) estimates that less than $10 \%$ t of non-refugee cases are reported. ${ }^{40}$

The ongoing violence against civilians has also resulted in a refugee crisis. As of November 30, 2009 , there were nearly 1.9 million internally displaced persons (IDP) in eastern DRC. ${ }^{41}$ The UN 
Office for the Coordination of Humanitarian Affairs (UNOCHA) estimates that one million of those fled their homes during 2009 (ref. 42). IDPs flee to host families, forest areas, and displacement camps. They have limited access to food and medicine. In North and South Kivu there are 47 camps hosting 117,000 IDPs. ${ }^{43}$ Neighboring countries are feeling the pressure too. In January 2010, 125,000 refugees fled to the Republic of Congo (ROC) and Central African Republic (CAR). ${ }^{44}$ The effect of looting and burning on villages can be seen in satellite images collected by the American Association for the Advancement of Science (AAAS). For example, satellite imagery of Busurungi, Walikali on southern border of North Kivu displays evidence of May 2009 attacks by FDLR, see Fig. 2.1 and Fig. 2.2. Collected images show 1,494 destroyed structures within the 100 square mile bounds of the study with more destruction likely outside of the bounds of the imagery. ${ }^{45}$

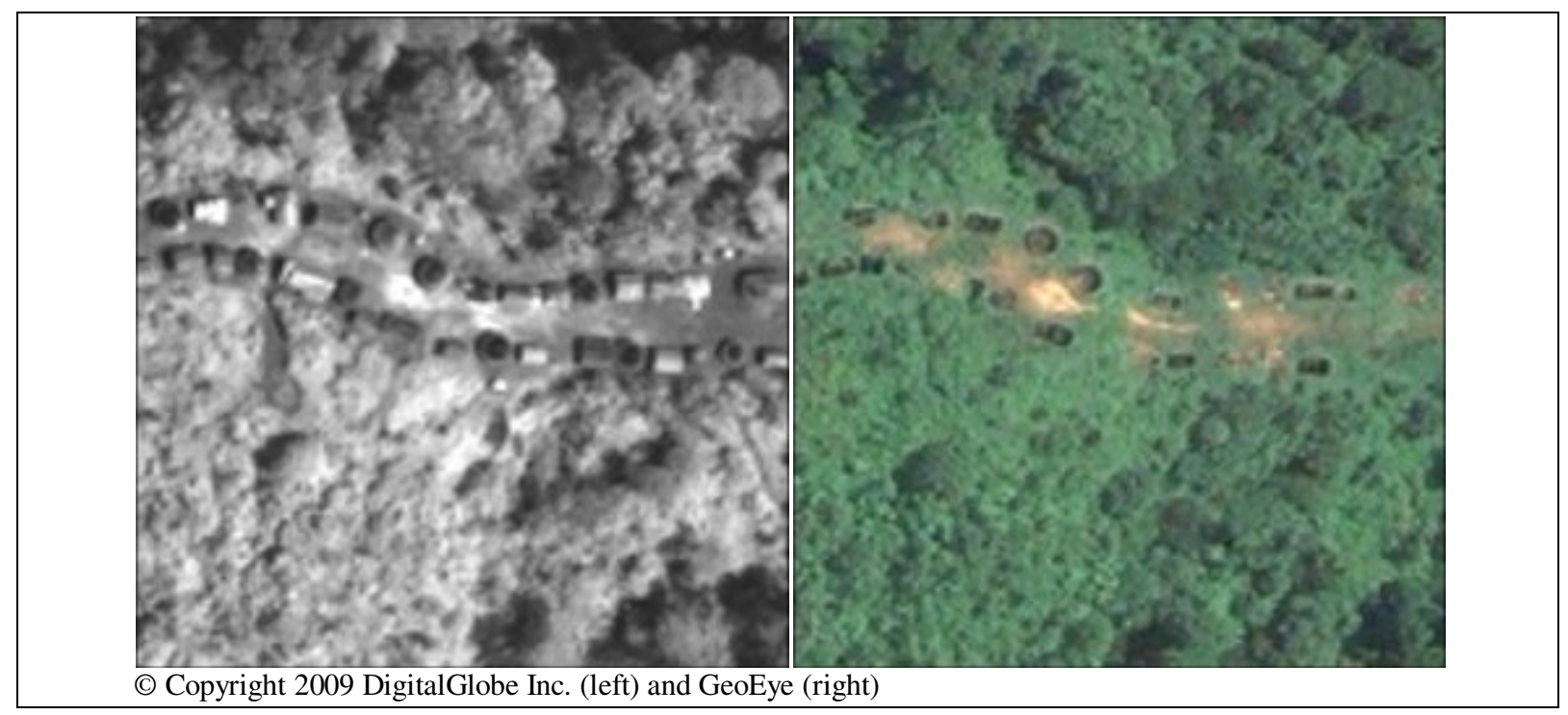

Fig. 2.1. A removed village. A close-up of a village in the area of Susarungi, intact on January 22 and evidently burned by September 22, 2009. This village had 103 structures destroyed. Latitude / Longitude: $1.672472^{\circ}, 28.583403^{\circ}$. 


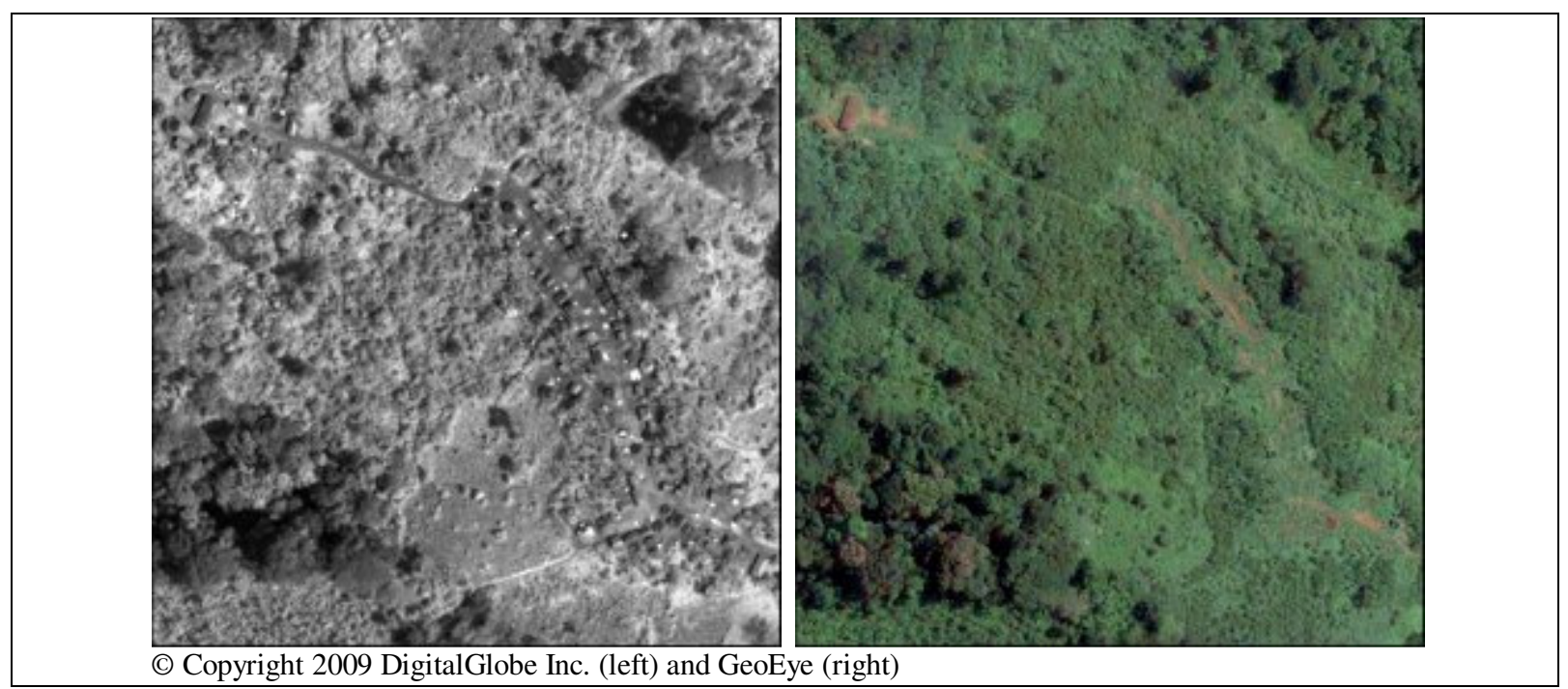

Fig. 2.2. A removed village. A close-up of a village in the area of Busurungi, intact on January 22, but 76 houses were destroyed by September 22, 2009. Latitude / Longitude: $-1.750283^{\circ}, 28.590028^{\circ}$.

Since January 2009, more than 6,000 homes have been burned down in the eastern provinces of North and South Kivu. ${ }^{46}$ 


\section{SOCIAL AND ECONOMIC CAUSES OF CONFLICT IN EASTERN DRC}

Explanations for armed rebellion fall into two categories, motivation and feasibility. Within the motivation category are the theories of greed and grievance. Causes of armed conflict attributed to greed are fairly straightforward: rebel organizations are motivated by financial gain and/or lust for power. ${ }^{47}$ In DRC rebel groups and militias seek to maintain or establish control of mineral wealth. Explanations reducing violent conflict to greed for economic resources are simplistic, ignoring other complex motivating factors, ${ }^{48}$ but in the Congo sustaining armed conflict for financial gain has assumed priority over any initial political motivations by multiple actors who have found themselves involved in enormously profitable economic arrangements. ${ }^{49}$ The UN panel suggests that Rwandan and Ugandan military officers got a taste for riches that were available in eastern Congo through control of natural resource exploitation resulting from the first Congo war and this was a major factor in their involvement in the second Congo $\operatorname{war}^{50}$ (see Sect. 1 for more detail). The second motivation theory is grievance. Most traditional analyses attribute the motivation for armed rebellion to grievance, usually historical in nature. The grievance frame of violent civil conflict is reflected in popular perceptions of rebellion that view rebel groups as motivated by seeking justice for groups who have suffered social inequality.$^{51}$ There exist an array of legitimate grievances in DRC that are attributed to the cause of violent conflict from the effects of colonialism, Western intervention in Congo's leadership struggle following independence and the suspension of international economic aid at the end of the Cold War to ethnically motivated discrimination, conflict, land disputes; regional warfare; power; and security and survival. The common narrative of the conflict in eastern DRC often frames the root cause as grievance stemming from long standing ethnic tribal tensions between Hutu and Tutsi manifested as local groups squabbling over mineral wealth. ${ }^{52}$ Scholarly literature examining the causes of the conflicts in eastern DRC extends the grievance explanations to three main perspectives: an issue of state collapse, part of a continual trend, and foreign-policy-making of the states that intervene. ${ }^{53}$

While objective grievance may provide the desire for rebellion, it is not a sufficient condition for the initiation or continuation of armed conflict. For example, inequality, whether in income or assets, and lack of democratic rights has no discernible effect of the likelihood of armed conflict. ${ }^{54}$ Ethnic and religious diversity, widely credited to increasing the risk of violent conflict actually reduces risk. In a country as highly ethnically diverse as DRC, with over 200 ethnic groups, conflict based on ethnicity is actually rather difficult to achieve, as President Laurent Désire Kabila experienced. When Kabila fell out with his Tutsi dominated military in his effort to gain independence from Rwanda and Uganda he needed to recruit new troops to oppose them and he needed to provide these new troops with the motivation to battle their fellow countrymen. Because DRC is so ethnically diverse, the society is not divided into two large groups; Kabila had to recruit across ethnic boundaries to build a sufficient army to battle the forces under Rwandan influence. Kabila manufactured an encompassing ethnic grouping, the Bantu, of which all ethnic groups were a member, except the Tutsi. He fostered an inter-group hatred out of military necessity that previously had not existed. The war that began in 1998 was not caused by established ethnic divisions, but by manufactured divisions actively created by Kabila. ${ }^{55}$

Furthermore, explanations of rebellion based on grievance fail to account for the length of most civil wars and the rare occurrence of rebel victories. In the DRC, the violent conflict has persisted for more than 14 years. If rational motivation for rebellion is the attainment of social justice for the wider group, then the benefits should be reflected during prolonged conflict rather than consequent upon an, as yet, unattained victory. The length of the war heavily discounts the benefit of pursuing social justice by both time and risk. ${ }^{56}$ The more likely rational motivations for continued violence are due to the benefit to the rebel leadership. ${ }^{57}$ As it turns out, in the DRC, rebel groups either have the objective of natural resource predation, or are critically dependent upon natural resource predation to pursue other objectives. For example, the CNDP propagates the "ethnic tension" grievance narrative, 
claiming that it is protecting the Tutsi minority living in eastern Congo from Hutu "genocidaires" who fled from Rwanda in 1994. In a December 2006 political manifesto CNDP outlined eight principal objectives for which it is supposedly fighting. They emphasized putting an end to the presence of foreign armed groups on Congolese soil, particularly the FDLR; the return of 45,000 Congolese Tutsi refugees abroad; an independent investigation into the war crimes committed on Congolese soil between 1998 and 2004; an alternative to the brassage integration process for FARDC; and the federalization of the DRC ${ }^{58}$ However, the actions of the CNDP and their leader, General Laurent Nkunda, indicated that they cared more about the Tutsi territory than the Tutsi people. Prior to January 2009 Nkunda controlled two zones in the 'Petit Nord' area of North-Kivu where mineral deposits are found, including the mining sites of Lueshe and Mumba/Bibatama where CNDP levied taxes of one dollar per kilogram on minerals recovered by diggers. Nkunda's primary method of profit, however, was through extortion and the imposition of "taxes" at barriers along trade routes for minerals, timber, and other goods. In September 2007 close to one million people paid taxes to Nkunda. ${ }^{59}$ Two barriers were particularly lucrative: $\$ 10,000$ per week was collected by taxing vehicles passing a barrier situated on the road from Walikale to Goma at the level of Mushaki-Nkuda and at a barrier in Kitchanga on the road linking Peti to Sake/Goma, timber trucks paid $\$ 150$ to pass and others were required to give a certain amount of fuel to the rebels. ${ }^{60}$ In addition to the profit Nkunda made off the territory of the people he claimed to be protecting, his very presence was a serious security liability for the residents in the area. According to a report from Human Rights Watch (HRW), "Nkunda-affiliated units killed, raped, and otherwise injured scores of civilians" in the first half of 2007 in several villages of Masisi and Rutshuru in North Kivu, often because of supposed collaboration with the FDLR. ${ }^{61}$ In August 2008 General Nkunda began engagement of a "serious escalation of fighting" in North Kivu, ${ }^{62}$ complaining again that Congolese soldiers and Hutu militia were a threat to his Tutsi brothers and sisters and he was rising up in resistance against the threat of more violence against the Tutsi in eastern Congo. Yet, in a call for negotiation during a ceasefire, Nkunda voiced his opposition to a \$9 billion Sino-Congolese deal that would have allowed China access to Congo's vast mineral reserves in exchange for infrastructure improvements. For someone whose main concern is the protection against the massacre of Tutsis, control of mining rights was an odd sticking point for ceasefire negotiations. ${ }^{63}$

Actions speak louder than words. For all the rhetoric about social justice espoused by rebel groups in DRC, these groups' true motivations are revealed by their patterns of behavior. A more likely explanation for violent armed rebellion is the feasibility hypothesis, which states that where rebellion is materially feasible it will occur. The two most important material conditions are financial and military. ${ }^{64-66}$ Neither greed nor grievance is an accidental by-product of conflict. Rebel groups manufacture a discourse of grievances to motivate their recruits and to raise funds among international diaspora, who the groups depend on financially. Rebel groups also engage in predatory behavior (i.e., the use of force to extort goods or money from their legitimate owners) to sustain themselves financially. ${ }^{67}$ The FDLR is a prime example of an armed group whose original objective was not exploitation of natural resources but whose unfettered access to those resources for the past 14 years has allowed them to set up efficient and extensive business networks as well as political, economic and social structures and administration in the regions they control. ${ }^{68}$ The UN Group of Experts estimates that FDLR's profits from natural resource exploitation are worth millions of dollars a year and described the FDLR's trade in minerals as a high priority objective. ${ }^{69}$

Civil conflict is much more strongly related to economic and geographic variables than it is to objective grievance, ${ }^{70}$ pointing toward the feasibility explanation. Studies of the factors that increase the risk of civil conflict demonstrate that certain conditions must be present for violent civil conflict and these factors, rather than objective grievance, explain root cause. The factors that significantly influence the likelihood and continuation of armed conflict are materiality; political economy; geography and lootability; ${ }^{71-72}$ and the proportion of young men (15-29 years of age) in the total population. ${ }^{73} \mathrm{~A}$ comprehensive empirical analysis of 71 wars for 172 countries on the cause civil war, defined as large scale organized violence on the part of a rebel army, was conducted by Collier and 
his colleagues in 2006 (ref. 74). The study focused on discerning motivation (i.e., greed and grievance) and feasibility by collecting a wide variety of economic, political, sociological, geographic and historical variables to analyze. The analysis found specific material conditions were significant, and these, rather than objective grievance, are the risk factors that explain civil conflict. The results of the analysis supported previous findings ${ }^{75-76}$ that economic characteristics are a significant cause of rebellion, namely the level, growth and structure of income. Additionally, three new variables emerged as significant and quantitatively important. These are whether the country was a under the French security umbrella during 1965-1999, the proportion of the country's population who were males age 15-29 during the period of conflict, and the extent to which the terrain is mountainous. The significance of these three variables is they decisively point to a causal explanation of feasibility over motivation. Also notable are the factors that proxy motivation that were found to not be quantitatively significant: the Cold War, the degree of democracy, population density, having had a previous war, a range of variants of ethnic diversity, the number of years since Independence, fuel exports, and income inequality. In regard to the Democratic Republic of Congo, these variables are significant and provide a more clear explanation of the ongoing violent conflict, rather than the grievance narratives.

The three significant economic variables that drive civil war are present in DRC. First, countries with low level of per capita income have more than a five times higher rate of civil war. This effect was also found in another major global quantitative study by Fearon and Laitin (2003) (ref. 77). The World Bank classifies the DRC as low income ${ }^{78}$ and with an annual per capita income of $\$ 171$ in 2009 (ref. 79), DRC is among the poorest countries in the world. Interpretations for the correlation between low per capita income and likelihood of civil war are that it reflects the effectiveness of the state, and thus the ability of the government to deter rebellion ${ }^{80}$ as well as the opportunity cost of time and therefore, the cost of rebel recruitmen. ${ }^{81}$ Both explanations are relevant to Congo. The country has suffered decades of government mismanagement and corruption. The Congolese government cannot control its territory, provide basic services or effectively protect its population. ${ }^{82}$ Additionally, the endless nature of the Congo wars has supported rebel recruitment. Even with the fluid composition of the militias and territories they control, rebel groups have solidified loyalties among rebel fighters and when necessary they forcibly recruit young boys. The second economic factor, the growth rate of countries in the five-year period prior to conflict (gross domestic product (GDP) per capita), is significantly correlated with risk of conflict, with an average GDP per capita of $-0.5 \%$ for conflict countries compared to $2 \%$ for peaceful countries. The effect of growth rate of income is supported by research using Africa-only data. ${ }^{83}$ For the five-year period prior the civil conflict in 1993 leading to the overthrow of Mobutu Sese Seko, the average growth rate of GDP per capita in DRC was $-5.26 \%$. Prior to the outbreak of the 1996-1997 war, the average growth rate of GDP per capita was $-7.12 \%$ and prior to the 1998-2003 war the rate was $-6.76 \%$ (ref. 84). The third economic indicator for likelihood of violent civil conflict is the structure of income, which is particularly relevant for countries rich in natural resources. Collier et al., ${ }^{85}$ proxy the richness in natural resources by the proportion of primary commodity exports (PCE) in GDP at the start of each period of war. They found the risk of dependence on PCE is at its peak when they constitute around 25\% of GDP. These results are supported by a study that found conflicts are more likely to be located in the areas of a country in which natural resources are extracted. ${ }^{86}$ Primary commodities exports appear to correlate to increased risk of conflict in three ways. Primary commodity exports can finance the escalation and sustainability of rebellion. In DRC for example, General Nkunda of the CNDP escalated violence in North Kivu in 2008 when a Sino-Congolese contract negotiation threatened his control of critical mineral trade routes that he directly profited from through taxation. ${ }^{87}$ Primary commodity exports may motivate rebellion by the desire to capture the rents, either during or after the conflict. The UN Group of Experts 2009 report concludes that 'FDLR's ongoing exploitation of natural resources in the Kivus, notably gold and cassiterite reserves . . . continues to deliver million of dollars in direct financing into the FDLR coffers." ${ }^{\prime 8}$ Finally, the governments of resource-rich countries tend to be more remote from their populations. Kinshasa, the capital of DRC, is not only located more than a 
1000 miles west of the capital cities of both North and South Kivu, but has had little to no control over the Kivu region since the overthrow of Mobutu.

The next three significant variables for risk of conflict point decisively toward the feasibility hypothesis ${ }^{89-90}$ over motivations of greed and grievance. These are whether the country was under the French security umbrella during the period 1965-1999, the proportion of young men in the total population, and the proportion of mountainous terrain in the conflict region. The French security guarantee seems to have radically lowered the risk of conflict during 1965-1999, with that security disappearing starting in the early 1990s after France began to cease military intervention, viewing it as unjustified support for tainted regimes. ${ }^{91-92}$ While DRC was not a French colony, the Congo was of great strategic interest to France. During the First Republic, France tended to side with conservatives and federalists and against Patrice Lumumba. After the Katangan secession was defeated in 1963, France signed a treaty of cultural and technical cooperation with Congo. Under President Mobutu's rule, France became one the regime's closest foreign allies responding militarily to Mobutu's calls for help during the Shaba invasions of 1977 and 1978 and later training and advising two Zairian airborne brigades. In 1989, France President François Mitterrand was the first world leader to write off Zaire's debt to his country. France was also slow to condemn the Mobutu regime after Belgium and the United States cut off their support, not pressuring Mobutu to reform until the French ambassador to Zaire was killed during rioting in 1993 (ref. 93). The next factor pointing toward the feasibility explanation, the proportion of a country's population of males 15-29 years of age, is significant, presumably because rebellion relies almost exclusively upon this segment of the population. The more young men available to fight, the more feasible the conflict is for rebel group. In the DRC, the median (estimated) age of males in 2010 is 16.3 years and $50.8 \%$ of the population aged 15-64 is male. (Collier et al., ${ }^{94}$ define the "young men" variable as the proportion of young men aged 15-49 of the total population (\%), Data Source: UN Demographic Yearbook. Statistics are not available for the aged 15-29 groups for many countries, including the Democratic Republic of Congo). Even when significant numbers of volunteers are not available, the proportion of young men in the country is significant because rebel groups forcible recruit among boys. This has become a common practice by armed forces active in the eastern provinces, North and South Kivu. ${ }^{95}$ The final variable significantly correlated with civil conflict is the proportion of the terrain of a country that is mountainous. The terrain of North and South Kivu in Eastern DRC, the provinces where most of the violent civil conflict occurs, is elevated mountainous. The region is bounded in the east by the Great Rift Valley, with average altitudes of 10,000-12,000 ft. The Rwenzori Mountains are located in this region on the border with Uganda. Figure 3.1 displays a topography map of the terrain of DRC. 


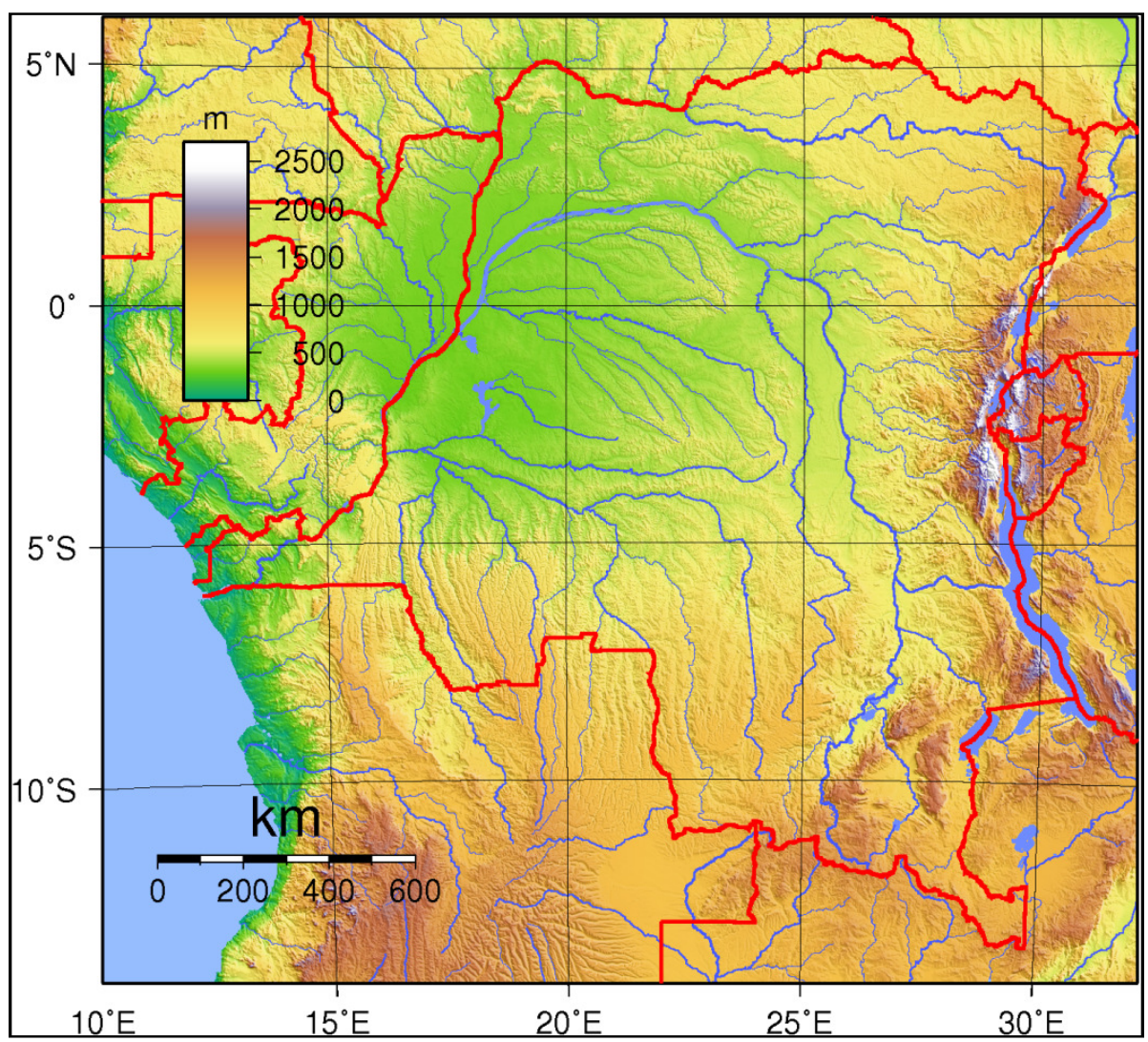

Fig. 3.1. Topographic map of Democratic Republic of the Congo. (Source: Wikipedia, 2007, http://en.wikipedia.org/wiki/File:Congo_Kinshasa_Topography.png).

\subsection{NATURAL RESOURCES IN EASTERN DRC}

Congo's economy has been dependent on the export of raw materials since it was colonized. Empirical evidence suggests that countries economically dependent on the export of primary commodities are at a higher risk of political instability and armed conflict, a phenomenon known as the "resource curse". ${ }^{96-99}$ Congo's natural resources include cobalt, copper, niobium, petroleum, industrial and gem diamonds, silver, zinc, manganese, uranium, coal, hydropower, and timber. The natural resources that fuel the current conflict and are the principle sources of revenue for armed groups and military units in eastern Congo are the 3Ts (tin, tantalum, tungsten) and gold. Natural resources and the likelihood and course of armed conflict in resource rich countries are directly linked by geography (availability) and lootability of the terrain. Geography plays a more central role when conflict is being fought over for control of natural resources. The spatial distribution and lootability are crucial to the opportunities of rebels to seize and retain control over resource revenues. ${ }^{100}$

According to the abundant resource wars argument, primary commodities play a vital role in funding conflicts because they are easily looted and taxed and require a minimal bureaucratic infrastructure. Therefore, governments and rebel groups can enter the resource extraction business through minimal investment; often simply controlling the territory is sufficient. In conflict, natural resources represent the reward of territorial control. ${ }^{101}$ Additionally, because the source for extracted resources is fixed, legitimate resource business operators desire to protect access and control to their sites, even when they are not investing in or undertaking current operations. Access is maintained by paying taxes to 'whoever is in power'. ${ }^{102}$ This can take several forms from paying a few dollars to let a truck pass a checkpoint to multi-million dollar concession signature bonuses paid to belligerents. In resource rich areas, rebel groups often seek to establish permanent strongholds around resource 
extraction sites and along transport routes to collect taxes to fund their operations. The focus of military activity becomes centered on these areas. ${ }^{103}$

There are four geographical dimensions that shape armed conflicts involving the control of natural resources. ${ }^{104}$ The first is proximate or distant location. The further the available natural resources are from the country's capitol, and the closer to the border, the more likely they are to be captured by rebels. Gem mines in remote border areas tend to be overrun by rebel groups and integrated into their armed conflict economy. ${ }^{105}$ The conflict in DRC is fought primarily in the provinces of North and South Kivu in eastern DRC located along the borders with Rwanda, Uganda, Burundi, and Tanzania and more than 1000 miles from Kinshasa. As displayed in Fig. 3.2, this area is rich in extractive resources. The second dimension is point or diffuse concentration of resources. Point resources (or point source) are concentrated in an area while diffuse resources are more widely spread. Resources exploited by the extractive industries are mostly point resources and diffuse resources are those exploited by productive industries (i.e. agricultural, forestry, and fisheries). Fragmentation of the society and economic activities is the third feature, as people tend to regroup in safer areas during armed conflict. This redistribution of the population leads to a reconfiguration of economic activities and socio-political structures. The last component is peripheralism of society and the economy. Transborder trade replaces internal trade due to the insecurity within the territory. This aggravates capital flight and import dependence. Border towns and internal trading gateways increase in importance. 'Satellite populations' composed of diaspora and refugees emerge and new hubs of power develop as large populations of refugees come under the control of political factions. In the DRC, Rwandan Hutu militias who fled Rwanda following the genocide of 1994 took control of Tutsi refugee camps, and eventually much of the territory within eastern DRC, and have played a pivotal role in several of the rebel groups that have responsible for the fighting.

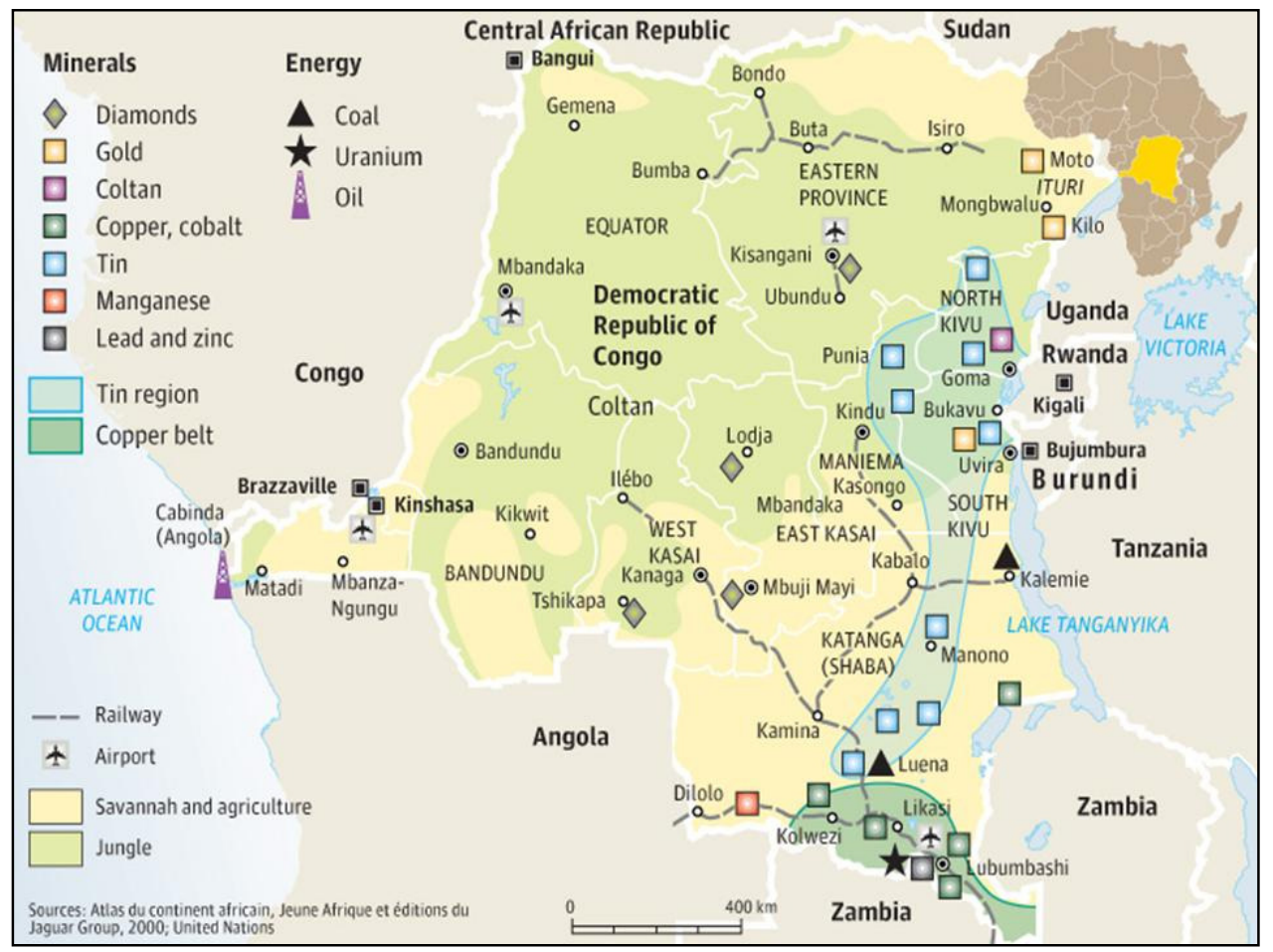

Fig. 3.2. Democratic Republic of the Congo mineral resources map. (Source: Atlas du continent aficain, Jeune Afique et editions du Jaguar Group, 2000; United Nations). 
When exploitation of primary commodities is easy, the personal wealth to be gained is attractive to those who control resource rich territories and their competitors. An economy of networks is created as a result of armed conflicts fought over control of natural resources which helps to prolong the conflict as different actors in the network seek to protect their economic interests. ${ }^{106-109}$ Congo is plagued by a pattern in which the political economy is rooted in dependence on the extraction of resources by networks of mostly private domestic elites, transborder commercial agents, and global markets. ${ }^{110-113}$ Investigations on the link between the wars in DRC and the exploitation of natural resources conducted by the UN Security Council Panel of Experts on the Illegal Exploitation of Congolese Resources support the idea that the DRC wars are driven by profits gained from the exploitation of natural resources. The UN Security Council stated that the control and exploitation of natural resources motivates and finances parties responsible for the continuation of the conflict in DRC. ${ }^{114}$ Foreign countries involved in the wars in Congo seek to maintain the significant economic interests they have developed in their exploitation of natural resources, hampering the Congolese government's efforts to control its resources and the mining sector. A separate UN Group of Experts examined these issues with regard to the apparent link between the illegal armed groups in eastern DRC and natural resource exploitation. The Group of Experts documented how armed groups in eastern DRC finance their activities through the illegal extraction of minerals ${ }^{115}$ and provided evidence of collaboration and support of Rwandan authorities ${ }^{116}$ as well as DRC government support of these armed groups. ${ }^{117}$ The Group of Experts also documented the human rights abuses, including attacks on civilians, carried out by armed rebel groups and FARDC as they seek and maintain control of high value territory. ${ }^{118}$ 


\section{SUPPLY CHAIN FOR CONFLICT MINERALS ORIGINATING FROM EASTERN DRC}

The UN Human Rights Council March 2010 report acknowledged the link between serious human rights violations, including "summary executions; sexual and gender-based violence; torture and other cruel, inhuman or degrading treatment or punishment; arbitrary arrest and detention; forced labour and extortion" 119 and illegal exploitation and trade of natural resources. The economic root causes of human rights violations in DRC stem from the illegal exploitation of natural resources, "either directly through violations linked to the actual exploitation and trade or indirectly because the proceeds finance unscrupulous armed groups and rogue FARDC elements." "20 Furthermore, the Council links the Congolese government's inability to finance and manage social and economic rights programs to the lack of transparent and effective government control over the mining sector. ${ }^{121}$

The UN Security Council Group of Experts on Illegal Exploitation of Natural Resources and Other Forms of Wealth of the Democratic Republic of the Congo investigation on the war economy provided extensive documentation demonstrating the economic link between the activities of armed groups on all sides of the conflict and the minerals trades. ${ }^{122}$ In 2008 the Group of Experts cited that the FDLR controls the majority of the mines in South $\mathrm{Kivu}^{123}$ and that the former CNDP, allied with the government since March 2009, controlled many of the trade routes through key border posts. Extensive involvement of the FDLR in the tin, tantalum and gold mines has been documented. ${ }^{124}$ For example, 1.97 tons of minerals were seized at the Goma airport from Congolese soldiers and militias in March 2008 (ref. 125). The FDLR and Congolese army are reportedly working together to trade minerals. ${ }^{126}$ Corruption, illegal export practices, and insecurity in the mining sector were estimated to cost the government of DRC $\$ 450$ million in revenue in 2008 (ref. 127) with rogue FARDC factions, armed militias and traders of cassiterite, coltan and wolfram all profiting. The profits earned by armed groups in Congo from the mineral trade in 2008 were estimated to be $\$ 185$ million. ${ }^{128}$ The 2009 report by the Group of Experts found illegal mineral exports to neighboring countries has significantly increased since renewed relations between DRC and Rwanda in January 2009 and the joint Army/MONUC Kimia II military offensive against the FDLR. ${ }^{129}$ (Kimia II commenced on December 31, 2009 as the humanitarian situation deteriorated resulting from reprisal killings and the displacement of more than 1.25 million people in North and South Kivu.) ${ }^{130}$ The Group of Experts has documented that factions of FARDC and other armed groups and associated cassiterite, coltan and wolframite traders have profited from the escalation of fraud. ${ }^{131}$

The natural resources fuelling the violence in Congo are gold and the 3Ts (tin, tantalum, and tungsten). These minerals are linked to human rights abuses by a supply chain for Western consumer products in which numerous actors continue to gain financially at each point in the chain, perpetuating the conflict. Tin, tantalum, tungsten are found in numerous locations throughout North and South Kivu, see Fig. 4.1 and Fig. 4.2. Tin ore is produced from cassiterite. Congo is the sixth largest producer of tin ore with 6-8\% of the world's supply. ${ }^{132}$ An estimated 24,592 tons of tin ore were exported from eastern DRC in 2008 (ref. 133). For comparison, the world production of tin ore in 2008 was 350,000 tons. ${ }^{134}$ Tin ore from cassiterite is a component in the production of solders, tin plating and alloys used in the electronics industry and for the production of tin cans. Tantalum ore is produced from "coltan" or columbite-tantalite. Coltan is a mineral concentrate containing the metals niobium (also known as columbium) and tantalum is found in many of the same locations as cassiterite in North and South Kivu. Cut-rate prices for tantalum from Central Africa, the DRC in particular, caused the closure of Australian tantalum mines in 2008 that had been the largest world producers driving Congo's share of tantalum world production to $15-20 \%$ of the total. ${ }^{135}$ The estimated production of tantalum in DRC was 155 tons compared to an estimated world production of 815 tons in 2008 (ref. 136). Tantalum is a component of circuits used for mobile phones, laptop computers, airbag protection systems, play stations, video cameras and digital cameras. ${ }^{137}$ Wolframite, or wolfram, is a mineral ore that is the source of tungsten. Congo is a minor source of world tungsten production, $2-4 \%$, but it is a growing source of financing for armed groups. 
Estimated production of tungsten in Congo was 1,300 tons $^{138}$ compared to a world production of 54,600 tons in 2008 (ref. 139). Tungsten is used in the production of hard metals (or cemented carbides), which are used to manufacture metal and stone cutting tools, mining tools and other heavy machinery components. It is also used in incandescent lamps, alloys and steels, and in the vibration alert function in mobile telephones. ${ }^{140}$

There are no reliable statistics available for gold but significant deposits of gold are found in South Kivu, see Fig. 4.2. The scale of fraud associated with the reporting of gold statistics is so enormous that the UN Group of Experts "does not consider gold statistics... worth detailing". ${ }^{141}$ Almost all gold exports are illicit and at least $90 \%$ of gold is undeclared. ${ }^{142}$ The Congolese government only documents a few kilograms in exports each year from North and South Kivu. The Enough Project estimates that 6.5 tons of gold were produced in eastern DRC in 2008 (ref. 143) and a DRC Senate report published in September 2009 estimated that more than 39 tons, or $\$ 1.24$ billion of gold, is smuggled out of DRC each year. ${ }^{144}$ It is known that gold is a critical source of financing for armed groups, especially the FDLR. The November 2009 Final Report of the Group of Experts notes that the use of gold by armed groups has increased markedly in the past few years owing to the ease at which it is smuggled and estimates that the gold trade is a significant source of direct financing for armed groups, particularly the FDLR, deriving several million dollars of revenue each year. ${ }^{145}$

The trade routes in which conflict minerals travel from the ground in Congo to the hands of consumers are well developed and can be illustrated in seven steps:

1. The mines in Eastern Congo

2. The trading houses in Eastern Congo

3. The exporters in Eastern Congo

4. The transit countries Rwanda/Uganda/Kenya

5. The refiners in East Asia

6. The electronics companies in East Asia/Europe

7. The consumers in the U.S./Europe 


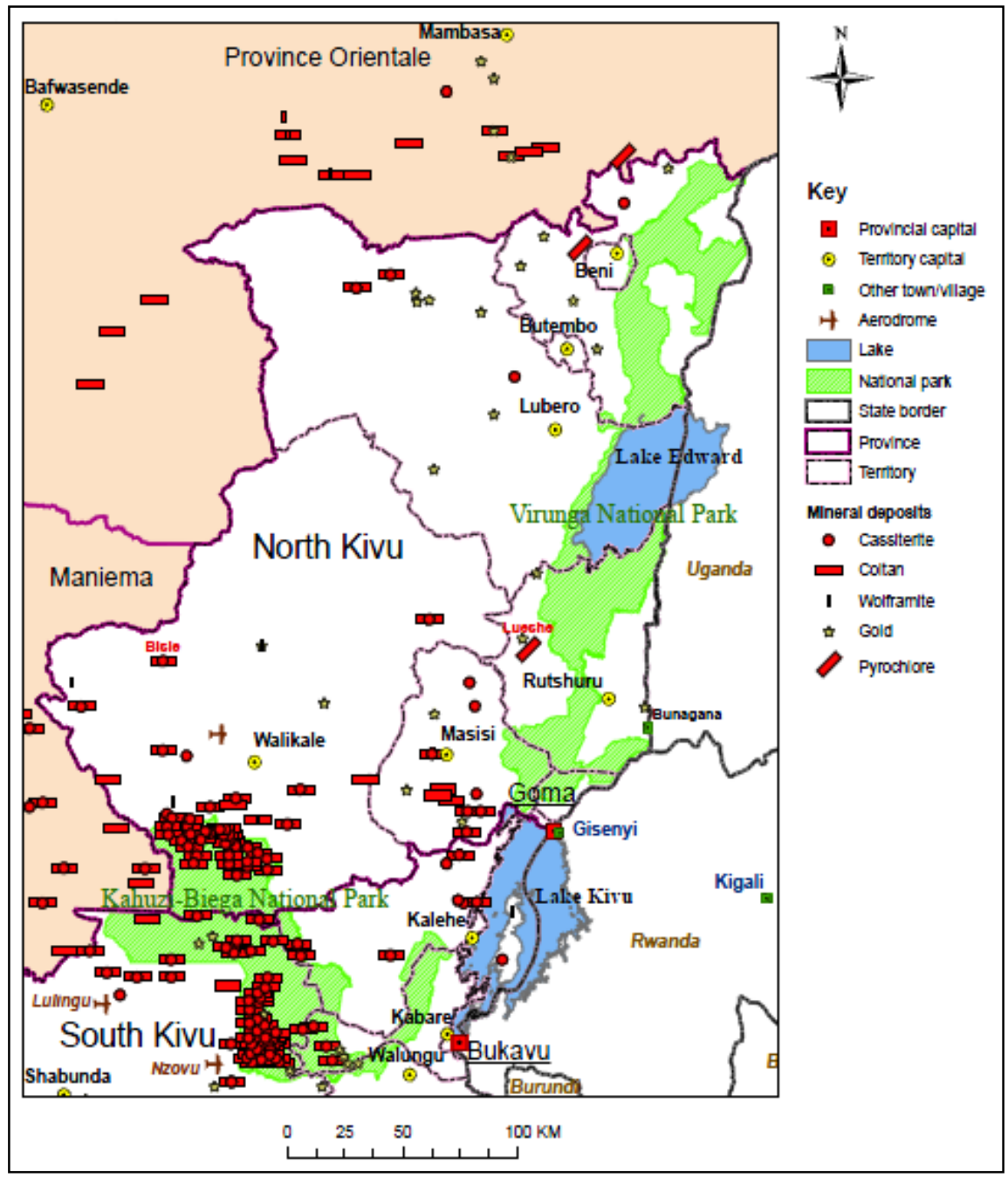

Fig. 4.1. Main mineral deposits in North Kivu. (Source: International Peace Information Service (IPIS), http://ipisresearch.be/mapping.php?\&lang=en) 


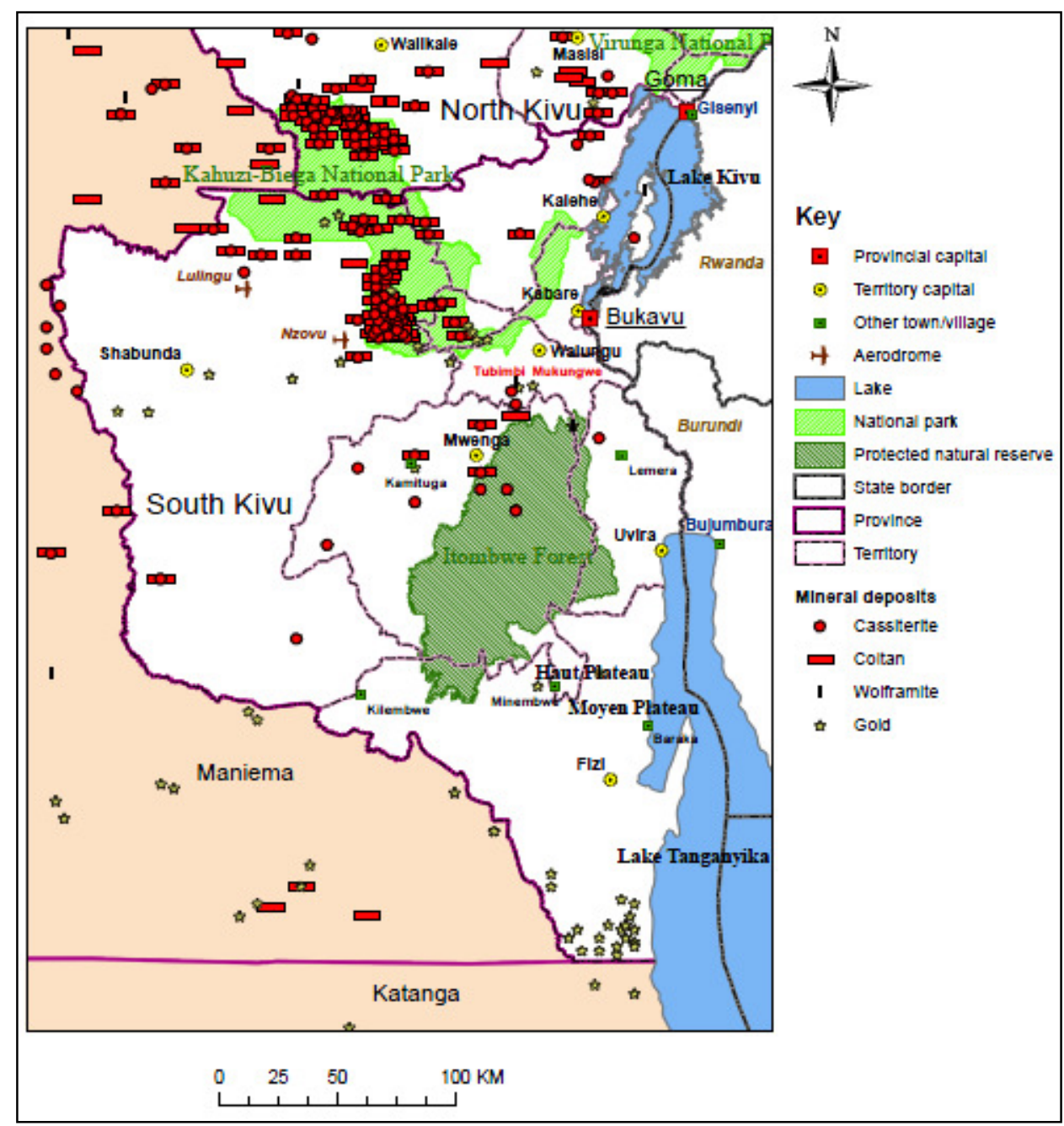

Fig. 4.2. Main mineral deposits in South Kivu. (Source: International Peace Information Service (IPIS), http://ipisresearch.be/mapping.php?\&lang=en)

8. 


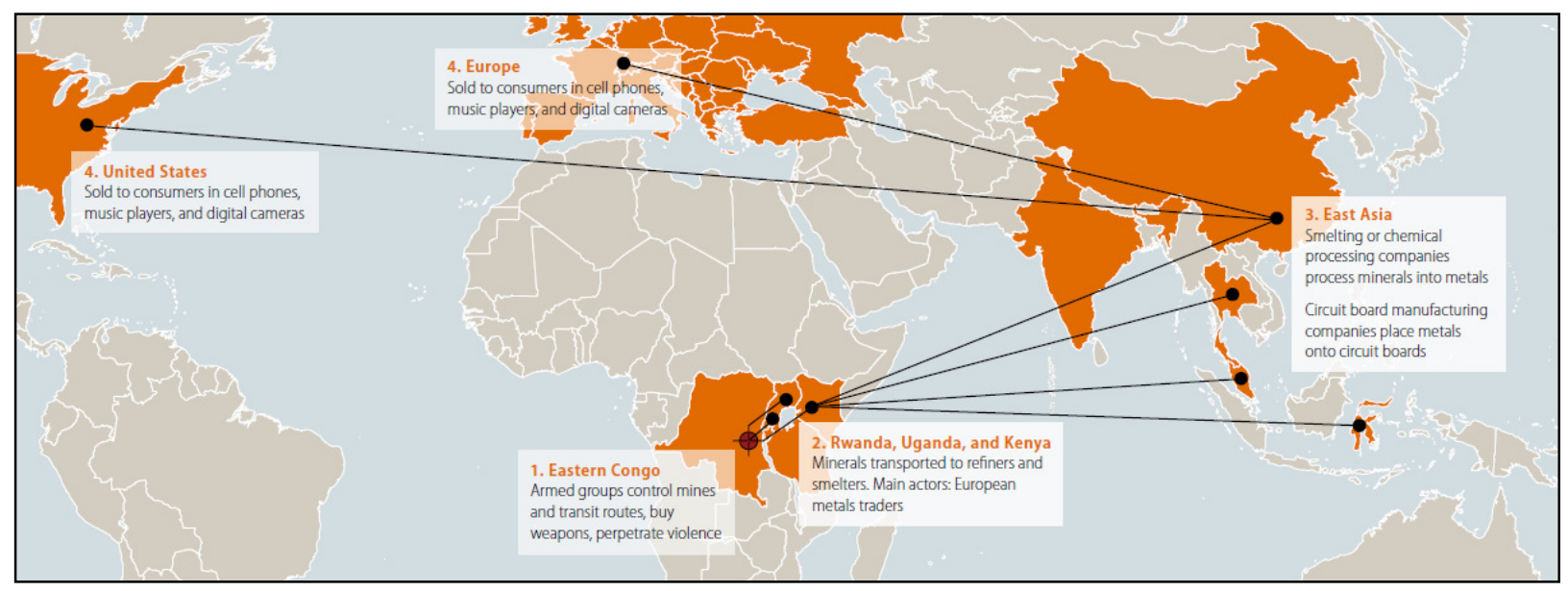

Fig. 4.3. Conflict minerals supply chain. (Source: The Enough Project, http://www.enoughproject.org/files/publications/Comprehensive\%20Approach\%20to\%20Congo's\%20Conflict \%20Minerals.pdf)

\subsection{THE MINES IN EASTERN CONGO}

Eastern Congo is the home to numerous mines located in remote areas of North and South Kivu beyond the rule of law. There are 200 mines in this region from large-scale operations employing as many as 2000 miners to mines that are no more than holes in the ground with a few workers. ${ }^{146}$ Thousands more work as porters or trade other goods around the mines. The mining industry in the region is unregulated and armed militias have established lucrative trading networks as a result of unrestricted access to the mines and their adjacent territories. ${ }^{147}$ At least $50 \%$ of all mines are controlled by armed groups and twelve of the thirteen major mines employing over 500 workers each are controlled by armed groups.148 All mining of conflict minerals in North and South Kivu is artisanal. $^{149}$ Workers are manual laborers who use their hands or simple tools to dig for mineral ore. All artisanal mining in the region is illegal under current Congolese law. Foreign and multinational mining companies continue to face difficulties establishing operations in North and South Kivu because of the presence of armed groups in the mines and general lawlessness in the region.

Control of the mines is fluid, passing back and forth between armed militias and soldiers from the Congolese army, who are in direct violation of Congolese laws that prohibit the presence of the army in the mines. ${ }^{150}$ The Kimia II offensive targeted key mining areas and trade routes removing the FDLR strong hold on the South Kivu region replacing them with Congolese army. However, these FARDC units are predominantly composed of former CNDP troops ${ }^{151}$ and often use the same tactics as the FDLR to exploit the resources and abuse civilians. The main perpetrator of rape against women in eastern Congo is now the Congolese army. ${ }^{152}$

Control of the mines takes various forms varying by site and armed group, from forced labor to commercial relationships with local chiefs, taxation, extortion, violence, and intimidation. In some areas FDLR extorts minerals and money from miners by charging a 30\% fee on mining proceeds and "taxes" minerals at roadblocks. ${ }^{153}$ FARDC has several methods of controlling the mines. At some mines a schedule has been set up in which particular days of the week are allocated for miners to work for soldiers and their commanders. FARDC soldiers also collect $10 \%$ of minerals and cash at military checkpoints along the roads. ${ }^{154}$ Individual FARDC commanders from the $8^{\text {th }}$ military region (North Kivu) and the $10^{\text {th }}$ military region (South Kivu) also own mines, taking a cut of profits and channeling the rest back up the military hierarchy. ${ }^{155}$ Senior military and political officials in the capital of Kinshasa are implicated in these schemes. ${ }^{156}$ And although the FARDC and the FDLR are fighting against each other, they collaborate through mutual agreement and profit sharing to control mining areas. ${ }^{157}$ The working conditions in the mines are deplorable and dangerous; fatal accidents 
and serious injuries are regular occurrences. There are no health and safety standards for mines extracting conflict minerals and child labor is common. The average worker earns $\$ 1$ to $\$ 5$ per day (World Bank) and many miners barely earn enough to feed themselves for the day, often trading small rocks for food. Meanwhile, armed groups earn up to $90 \%$ of the profits at some mines. ${ }^{158}$

Control of the Bisie mine in Wlikale, North Kivu is particularly illustrative of the situation. Bisie is the largest mine in the Kivu provinces supplying $80 \%$ of North Kivu's cassiterite production, ${ }^{159} 787$ to 984 tons of ore per month. From 2006 to March 2009, Bisie was controlled by the nonintegrated $85^{\text {th }}$ Brigade of the Congolese Army stationed in the region. The $85^{\text {th }}$ Brigade is a former Mai Mai militia operated outside the control of the Congolese government whose commander, Colonel Sammy Matumo, is linked to Congolese army officers who profit from the mine. ${ }^{160}$ The Brigade operated openly at the mine and collected at least $\$ 120,000$ a month by taking a commission of $\$ 0.15$ per $\mathrm{kg}$ of cassiterite mined from Bisie ${ }^{161}$ during 2007 and the first part of 2008. The $85^{\text {th }}$ Brigade was transferred out of area in March 2009, replaced by the $1^{\text {st }}$ integrated army Brigade composed of former CNDP members who had been through brassage and led by former CNDP commanders. This move effectively shifted control of the mine to the former CNDP. Under the $1^{\text {st }}$ integrated army Brigade's control, fraud and human rights abuse has escalated. Even more cassiterite is being shipped from Bisie to Kisangani, then Beni, Butembo and Goma, before being exported to Rwanda. ${ }^{162}$

\subsection{THE TRADING HOUSES IN EASTERN CONGO}

Minerals are transported out of mining areas to trading towns by porters who carry the minerals in $50 \mathrm{~kg}$ sacks on their backs in journeys lasting one to two days along what are often just rugged footpaths. From these towns the minerals are transported by truck and/or plane to the trading houses, maisons d'acha, located in major cities. Negociants, buyer-transporters licensed to buy in the field and sell to any domestic exporting company, act as intermediaries between the armed groups controlling the mineral sources and the comptoirs, licensed exporters, who buy the minerals at the trading houses. The trading houses are the gateway for minerals to enter the international market. The 3Ts and gold are traded in different cities. The 3Ts arrive in Bukavu and Goma where there are approximately 100 trading houses each. Gold is transported to the cities of Buembo and Uvira. Gold is easier to smuggle into trading houses than the 3Ts because it is much more valuable, $\$ 15,000 / \mathrm{lb}$ for processed gold versus $\$ 7 / \mathrm{lb}$ for processed tin. ${ }^{163}$ Negociants are normally paid in advance by the exporters for the minerals transported from the mines to the trading houses. The majority of the buyer-transporters and trading houses operate illegally without proper licenses and registration. Only one in ten transporters in Bukavu is officially registered with the Congolese governments. ${ }^{164}$

Armed groups also control the transport of minerals from mines to buying house, profiting greatly from mineral transport. For example, minerals from the Bisie mine are carried by porters to Kilambo where approximately 20 flights a day leave for Goma carrying more than 19 tons of cassiterite from an airstrip completely controlled by FARDC. ${ }^{165}$ An estimated $\$ 75$ million of the $\$ 180$ million earned by armed groups in 2008 from the mineral trade was profit extracted through control of mineral transport. ${ }^{166}$ Bribes and taxes are exacted from transporters and local and international buyers. Armed groups take a large percentage of profit (up to $\$ 40$ per sack) through road blocks that begin just outside the mining sites. They also transport the minerals themselves and have co-opted state institutions and traditional local authorities present in eastern DRC. ${ }^{167}$

Once the minerals arrive at the trading houses, they are sorted and processed for export. At this point in the supply chain it is still easy to identify the origin of the minerals. Minerals have coloration and texture depending on the mine of origin. Dealers at buying houses and government inspectors have knowledge of these characteristics. ${ }^{168}$ 


\subsection{THE EXPORTERS IN EASTERN CONGO}

The minerals are purchased from the trading houses and transporters by export companies, comptoirs, who process the minerals and sell them to foreign buyers (Table 4.1). By Congolese law, negociants and comptoirs are required to register with the government. However, the effect of license and registration is that it provides negociants and comptoirs with the cover of legal operating status, enabling foreign purchasers to claim they are buying from "legal" sources. Comptoirs normally prefinance the negociants who work closely with the armed groups. Comptoirs and negociants who trade in conflict minerals are well known to everyone in the trade. According to a Global Witness source:

"Everyone knows who the FDLR intermediaries are but they won't say in case it implicates them. The FARDC are also involved. Everyone, including the authorities, is involved [...] They all know each other but won't say [their names]. But we know which comptoirs they sell to in Bukavau [...] Muyeye,, MDM. They buy cassiterite, coltan and gold from

Shabunda, Mwenga, Homobo and Bunyakiri, either from FDLR areas or through the civilian population used by the FDLR. The intermediaries then send the minerals by plane or trucks to Bukavu. They sell to those particular comptoirs. Everyone know what's going on but the authorities don't control the situation."169

Official comptoirs are affiliated with the Fédération des Entereprises du Congo (FEC). The branch of the South Kivu FEC estimates that official comptoirs in the region exported 442 tons of cassiterite, 44 tons of wolframite, 16 tons of coltan, and $10 \mathrm{~kg}$ of gold each month during 2007 (ref. 170). There are 17 registered exporters in Bukavu and 24 in Goma. Comptoirs, like transporters, are paid in advance for their minerals by international traders located in Belgium, Malaysia, and other foreign countries. Verbal assurance is the only system in place to prevent exporters from buying conflict minerals and exporters do not refuse batches of minerals they believe to have originated in conflict mines. ${ }^{171}$

The UN Group of Experts has identified several major exporters as actively purchasing minerals from mines controlled by the FDLR and other armed groups. ${ }^{172-173}$ In North Kivu, several comptoirs source cassiterite from the Bisie mine in the Walikale area, including Sodexmines, Amur, Sodeem, Hill Side, and Pan African Business Group (PABG). Sodexmines, one of the largest comptoirs in North Kivu and one of the biggest buyers of cassiterite exported to Belgium, reportedly exports approximately seven containers a week weighing 22 tons each. ${ }^{174}$ Comptoir PABG acknowledges that it buys from and has representatives on site at the Bisie mine, as well as Njingala mine in Walikale and mines in Maniema province. ${ }^{175}$ The Group of Experts cited comptoir MH1 as sourcing coltan from a militarized mine operated by former CNDP elements in Masisi, North Kivu ${ }^{176}$ and comptoir Munsad was cited for buying coltan from the CNDP controlled mine, Bibatama, in North Kivu. ${ }^{177}$ In South Kivu, several comptoirs were identified by the Group of Experts as trading in conflict minerals sourced from the FDLR-controlled areas, including Group Olive, Etablissement Muyeye, MDM, World Mining Company (WMC), and Panju. These five comptoirs were the top five exporters of cassiterite, coltan and wolframite from South Kivu in 2007 (ref. 178). Huaying Trading Company (HTC), a Chinese-run comptoir based in Goma and Bukauv, was also cited as sourcing cassiterite from FDLR-controlled areas in South Kivu. ${ }^{179}$ The gold comptoir Etablissement Namukaya is cited as heavily involved in pre-financing gold purchases from FDLR in South Kivu. ${ }^{180}$ 
Table 4.1. North Kivu exports for August 2009 ${ }^{a}$

\begin{tabular}{llcll}
\hline Comptoir & Substance & Qty (metric tons) & Import firm & Country \\
\hline Amur & Cassiterite & 143.6 & Trademet & Belgium \\
Sodexmines & Cassiterite & 47.8 & S.D.E. Bruxelles & Belgium \\
Pan African Business Group & Cassiterite & 87.8 & Close Joint Stock Company & Russia \\
Huaying & Cassiterite & 90 & African Ventures & Hong Kong \\
Huaying & Cassiterite & 46 & Malaysian Smelting Company & Malaysia \\
Huaying & Cassiterite & 46 & Trademet & Belgium \\
Clepad & Cassiterite & 160.8 & Trademet & Belgium \\
Afromet & Cassiterite & 77.3 & Met Trade India Ltd. & India \\
GMC & Cassiterite & 23 & B.E.B Investment & Canada \\
Sodeem & Cassiterite & 99.2 & African Ventures & Hong Kong \\
TIT Mining & Cassiterite & 45 & Thailand Smelting and Refining & Thailand \\
MPC & Cassiterite & 20 & MPA Gisenyi & Rwanda \\
Hill Side & Cassiterite & 23.3 & MSA Limited & Rwanda \\
Donson & Coltan & 20 & Unilink Trading Ltd. & Hong Kong \\
MH1 & Coltan & 25.46 & African Ventures & Hong Kong \\
\hline
\end{tabular}

${ }^{a}$ (Source: The Enough Project, http://www.enoughproject.org/files/publications/DiggingInConflictMinerals.pdf)

MDM and Group Olive stopped registering any purchases of cassiterite from South Kivu beginning in June 2009, however the Panel of Experts has documented that MDM continues to purchase from FDLR mines. Evidence also documents that WMC, Etablissement Muyeye, Panju, and HTC have continued to trade in cassiterite originating from FDLR-controlled areas throughout 2009 (ref. 181). These efforts of comptoirs to hide their activities suggest that they are feeling pressure from the UN investigations. But these investigations name companies, not individuals, and there is evidence that some companies suspended operations to avoid sanctions and continued trade under new company names. For example, Bukavu-based comptoir MDM suspended its operations but continued trading in minerals from FDLR controlled mines under the name of another comptoir, WMC. ${ }^{182}$

Gold is smuggled out of DRC through two principal channels, the North Kivu-Uganda networks and the South Kivu-Burundi networks. In North Kivu, FDLR controls and taxes many gold mining zones in the Lubero and collaborates with Mai Mai groups to exploit several mines in Lubero and Walikale territories. ${ }^{183}$ Gold from these mines is sold to three principal gold traders in Butembo, North Kivu. In 2008 these three traders formed Glory Minerals in 2008, which claims that their gold supply "complies with United Nations standards," 184 but is cited by the Group of Experts as sourcing gold from FDLR-controlled areas. From Butembo, the gold is smuggled to Kampala, Uganda and on to Dubai. There are two family-run gold trading businesses who are the main suppliers to Kampala and Dubai, exporting up to several hundred kilograms of gold each per month. Both families prefinance trusted intermediaries who offer slightly above market prices to local DRC traders to control the market, while making back their margins on the savings they incur through avoiding paying official export taxes ${ }^{185}$ a normal practice for exporters of conflict mineral. In South Kivu FDLR and Forces Républicaines Fédéralistes (FRF), a small Banyamulenge-dominated militia group historically linked with CNDP, controls several different gold mining areas and most of the gold produced is sold to Mutoka Ruganyira in Burundi, ${ }^{186}$ (see next section).

\subsection{THE TRANSIT COUNTRIES, RWANDA/UGANDA/KENYA}

Exporters typically send the minerals to neighboring countries of Rwanda, Uganda, and Burundi by road, boat, or plane. Occasionally minerals are directly exported to international refiners or metals trading companies in Europe. Some conflict minerals are exported legally with taxes paid, but the vast majority are smuggled across the Congolese border and relabeled as having come from Uganda, Rwanda, and Burundi. Figure 4.4 displays the transit routes for mineral exported from eastern DRC. 
For example, Uganda officially produced less than $\$ 600$ worth of gold in 2007 , but exported over $\$ 74$ million worth of gold ${ }^{187}$ and Rwanda produced $\$ 8$ million worth of tin ore but officially exported at least $\$ 30$ million worth of tin. ${ }^{188}$ The buying houses in Uganda, Rwanda, and Burundi rarely ask questions regarding the origin of the minerals.

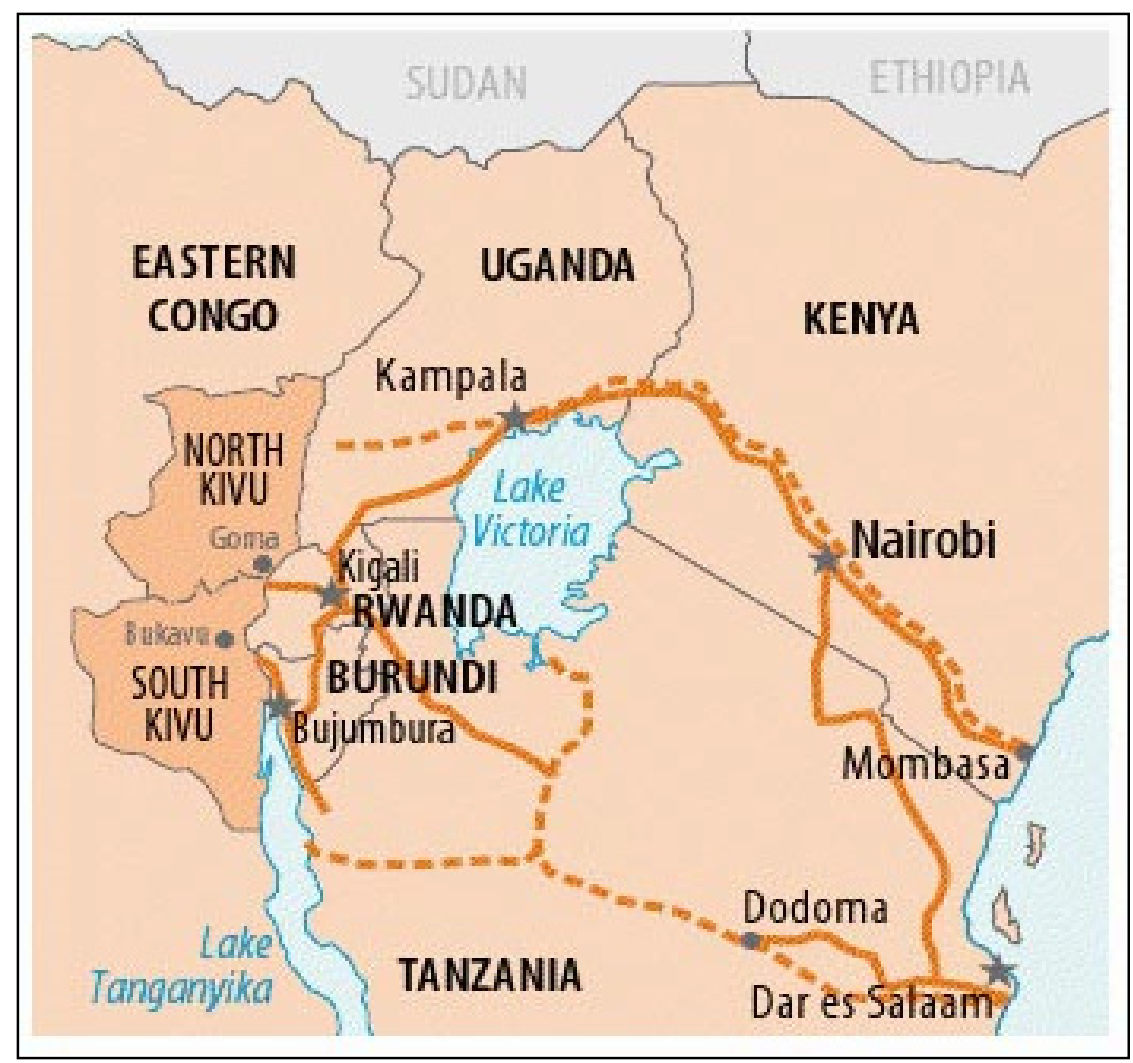

Fig. 4.4 Congo conflict mineral traffic map. (Source: The Enough Project, http://www.enoughproject.org/files/publications/minetomobile.pdf)

Rwanda imports and re-exports significant quantities of minerals originating from eastern DRC. Rwanda's Minister of Mines reported that approximately a quarter of its mineral exports in 2008 originated from DRC. ${ }^{189}$ Reports from other sources indicate that the figures are much higher. Customs declarations show that close to half of the minerals (by weight) exported from Rwanda were re-exports ${ }^{190}$ and the Rwanda Investment and Export Promotion Agency (RIEPA) reported that only $20 \%$ of Rwanda's coltan and wolframite exports were domestically produced in 2008 (ref. 191). The likely source of Rwanda's re-exported minerals is eastern DRC.

Minerals originating from South Kivu, especially gold, are primarily transported across Lake Tanganyika into Burundi to traders in the capital, Bujumbara. Seventy-five percent of the gold available comes from the DRC. ${ }^{192}$ There is only one licensed gold comptoir in Burundi, Mutoka Ruganyira, and he admitted to the Group of Experts that he purchased Congolese gold. ${ }^{193}$ Ruganyira is protected by security forces in Burundi and the DRC and high ranking Burundian government officials in customs and other agencies. Ruganyira maintains a web of pre-financing networks in Burundi and DRC and pays slightly above market prices. Nearly all gold exports from Burundi originate from Ruganyira's company, Berkenrode BVBA. From January 2009 through September $2009,912 \mathrm{~kg}$ of the $914 \mathrm{~kg}$ exported from Burundi were declared by Berkenrode BVBA. ${ }^{194}$ 


\subsection{THE REFINERS IN EAST ASIA}

International metal processing companies buy the minerals from the comptoirs to refine and sell to processing and manufacturing companies on the world market. The Belgian companies Traxys, Trademet, SDE, STI, and Specialty Metals imported the largest proportion of cassiterite, wolframite and coltan from North and South Kivu in 2007 (ref. 195). Thailand Smelting and Refining Corporation (Thiasarco), a Thailand-based tin smelter subsidiary of London-based Amalgamated Metals Corporation (AMC) was the second largest importer of cassiterite from North and South Kivu in 2007 followed by the British Afrimex; MPA, a Rwanda-based subsidiary of South-African owned Kivu Resources; Malaysian Smelting Corporation Berhad (MSC); and companies based in China, India, Austria, the Netherlands, and Russia. ${ }^{196}$ Thiasarco, the world's fifth largest tin-producing company, along with MSC are the two major smelters known to source from Congo. ${ }^{197}$ Thiasarco's trading practices have been cited as fuelling the conflict in DRC. ${ }^{198}$ Panju, a comptoir identified by the Group of Experts as pre-financing negociants who work closely with the FDLR, ${ }^{199}$ is Thiasarco's main supplier in South Kivu. Statistics provided by the Congolese government show Thiasarco purchased minerals from Panju in 2007 and 2008 (ref. 200-201) and the Group of Experts reported that all of Panju's purchases were sold to Thiasarco. ${ }^{202}$

Refiners who have been named by the UN Panel of Experts as knowingly purchasing from sources linked to the FDLR have come under intense pressure from the United Nations and international campaigners to reform their purchasing practices. Traxys, who purchased 1,631 tons of the tin ore cassiterite and 226 tons of coltan from comptoirs Groupe Olive, Panju, WMC, MDM, and Etablissement Muyeye in 2007 (ref. 203), suspended purchasing minerals from eastern Congo in May 2009. In September 2009 Thiasarco announced it would suspend purchasing from Congo. ${ }^{204}$ However, the wording of the announcement that they will "continue to honour existing contractual commitments," suggests purchase of Congolese minerals continues. In October 2009 the Congolese government asked Traxys and Thiasarco to resume their tin ore purchases from DRC after endorsing a supply chain monitoring scheme. ${ }^{205}$

The refiners are the critical link in the supply chain for tracing the origin of conflict minerals. Minerals from DRC are smelted, or chemically processed, with metals from other countries in large furnaces. Once the minerals are smelted, it is impossible to identify their origin. For tin, the main smelting companies process over $80 \%$ of the world's tin. ${ }^{206}$ For tantalum, four companies based in Germany, the U.S., China and Kazakhstan, dominate the chemical processing market. For tungsten, there are several processing companies based in China, Australia, and Russia. The main destination for gold is Dubai but recent records indicate that gold is being sent to Switzerland, Italy, and Belgium for processing. ${ }^{207}$

\subsection{THE ELECTRONIC COMPANIES IN EAST ASIA/EUROPE}

The single largest consumer of minerals from eastern Congo is the electronics industry. Refined conflict minerals are used to build the circuit boards and computer chips for electronic products such as cell phones and laptops sold to consumers by mainstream companies such as Nintendo, HP Dell, Intel, Apple, and RIM, the maker of BlackBerry. Other industries have a significant stake in conflict minerals, including tin can manufacturers, industrial tool and light bulb companies, aerospace and defense contractors, as well as the banking and jewelry industries. Currently there is no system in place to trace the minerals used in electronics and all cell phones and laptops may contain conflict minerals. Manufacturers settle for assurances from suppliers that minerals do not originate from conflict areas in eastern Congo. Although electronics companies continue to claim that either their products don't contain conflict minerals because their suppliers say so or that they cannot determine the origin of the minerals in their devices, the truth is they can. Conflict minerals continue to be used in the manufacture of countless consumer products using the excuse that the supply chain is too opaque. $^{208}$ 


\subsection{THE CONSUMERS IN THE U.S./EUROPE}

The final destination for conflict materials is the Western consumer, see Fig. 4.5. Western consumers are inadvertently underwriting armed militias fighting in the deadliest war in the world when they purchase everything from cell phones, cameras, music and game players, laptops, light bulbs, jewelry, and even soda sold in cans. Consumers are the final critical link in the supply chain and they can effect change by demanding that companies produce products free of conflict minerals. In a similar situation, consumer pressure on the diamond industry, via the 'blood' diamond campaign led by Global Witness, led to the adoption of the Kimberly Process Certification Scheme to assure consumers that they are not financing war and human rights abuses when purchasing diamonds. A campaign to certify conflict minerals is currently under way, led by several non-governmental organizations (NGO). The actions of concerned consumers led to the inclusion of a key provision on conflict minerals into the Dodd-Frank Wall Street Reform and Consumer Protection Act passed by Congress on July 15, 2010 and signed into law on July 21, 2010 by President Obama. The provision requires companies that use gold or the 3Ts in their products to file a disclosure report with the Securities and Exchange Commission (SEC) detailing the origin of these materials. It also requires companies to audit these reports to prove whether they are sourcing from conflict mines or not. Consumers pressured their elected officials and electronics companies during a Facebook campaign that filled their pages with messages demanding change. Consumers also made phone calls and faceto-face demands for the industry to clean up the supply chain and are responsible for the provisions inclusion in the overall bill. These campaigns and the recent media attention from the New York Times, ${ }^{209}$ the Huffington Post, ${ }^{210}$ and a viral video spoof ${ }^{211}$ of the "I'm a Mac..." ad led to the first ever response on the issue from Apple founder, Steve Jobs. ${ }^{212}$

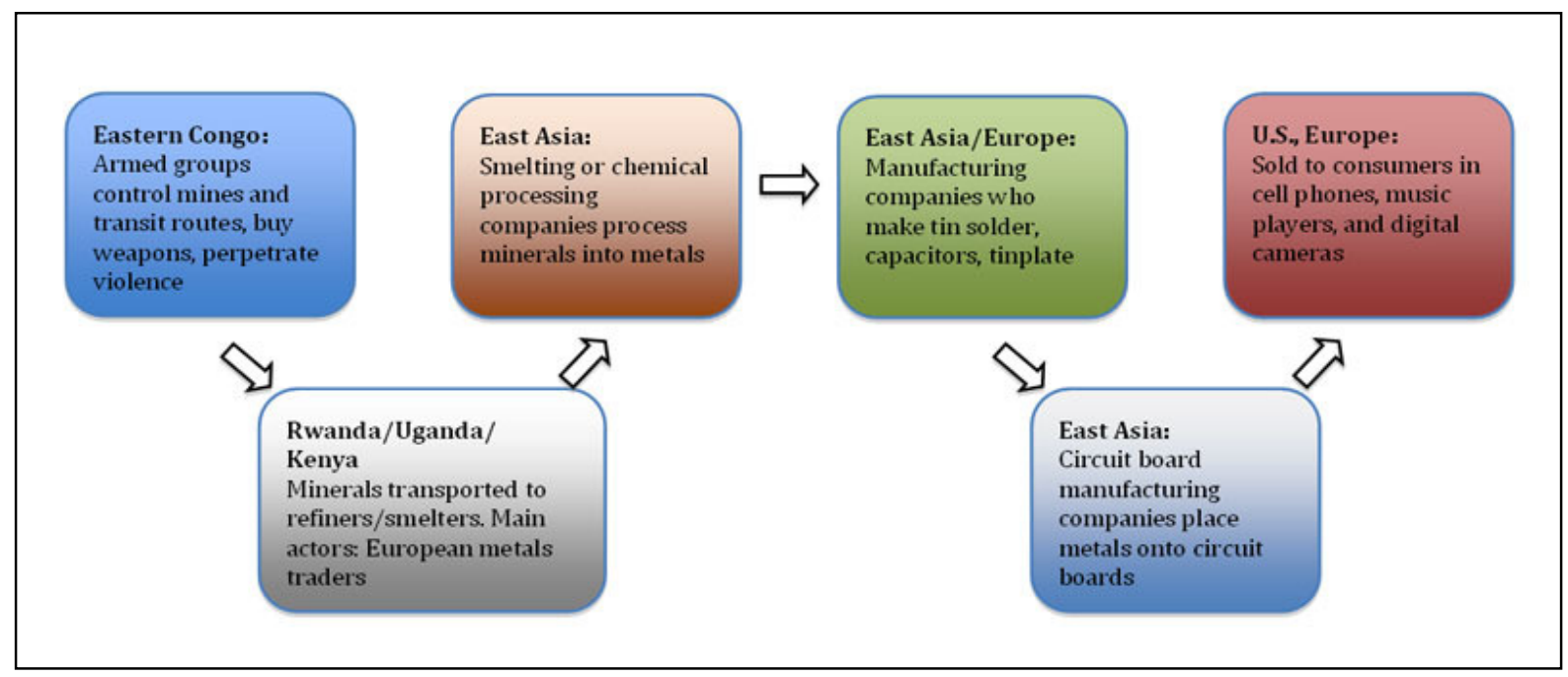

Fig. 4.5. Flow diagram of Congo's conflict minerals supply chain. (Source: The Enough Project, http://www.enoughproject.org/files/publications/Comprehensive\%20Approach\%20to\%20Congo's\%20Conflict \%20Minerals.pdf) 


\section{CONCLUSION}

The Democratic Republic of the Congo's dependence on the export of raw materials has destabilized its economy in many ways. DRC is continuously vulnerable to fluctuations of commodity prices in the international market, affecting its ability to repay national debt and fund national programs. ${ }^{213}$ The dependence on the export of commodities has also led to the neglect of the agricultural sector with Congo importing foodstuffs and consumer goods that are in high demand in urban areas instead of producing its own goods. The production of goods such as timber and palm oil has been largely taken over by Congo's neighbors. ${ }^{214}$ The people of DRC have adapted to year after year of weak, decentralized government and economic instability by creating an informal economy, making it all the more difficult for the Congolese government to establish rule. The informal sector is estimated to be at least three times the size of the official economy. ${ }^{215}$ Since 1994, vast quantities of Congo's wealth has “flowed across its borders, into Rwanda, Uganda, Angola, Zimbabwe, and other countries...At the same time, it must be recognized that large-scale misappropriation of wealth has been practiced within the country...pillagers of Congo include the Congolese." 216 The result has been a steep decline in the GDP and tax revenues. The money that the government needs to provide security, social services, and infrastructure is not collected by the government.

The Congolese people have benefited little from their natural resources. The country's natural resources have been the basis of war, but they can also form the basis for development. ${ }^{217}$ Mineral resources are central to development in many resource-rich countries. In these countries, minerals sustain livelihoods of the citizens and provide the principal source of revenue for states to finance security and social programs and to invest in infrastructure, agriculture and other productive industries. ${ }^{218}$ Even as the conflicts have continued, DRC's mineral trade sustains up to twelve million livelihoods in DRC, ${ }^{219}$ albeit in dreadful conditions. There are several reasons that the mineral trade does not currently produce more widespread development benefits for the DRC, including:

- patchy and locally negotiated governance that undermines development progress

- a contested monopoly of violence and resulting insecurity

- dilapidated infrastructure

- insufficient, costly and unreliable energy

- operationally difficult export regimes

- lack of transparency

- lack of sector development strategy, discouraging investment

- severely damaged agricultural infrastructure

- very limited access to finance. ${ }^{220}$

The trade in minerals from DRC cannot simply be stopped or interrupted. Creating a certification system will help companies in the supply chain and ultimately, consumers ensure that they are not purchasing conflict minerals. Recommendations for bringing transparency to the supply chain for conflict minerals originating from DRC have been proposed by many organizations based on the Kimberley Process for diamonds. ${ }^{221-224}$ The Kimberly Process is a certification scheme set up in 2003 to combat the trade of 'blood' diamonds. The process was designed to prevent armed rebel groups from using profits derived from the illicit trade in diamonds against legitimate governments. One of the current failures of the Kimberley Process is due to the fact the state governments profit in the illegal trade of diamonds. The successes and failures of the Kimberly Process provide an opportunity to shape the creation of a system to certify Congo's conflict minerals. However, it must be part of a multi-pronged approach. An overall strategy will create a sustainable, formalized mining sector by establishing transparency in the supply chain, identifying and securing strategic mines, improving governance of mining and trade, and supporting livelihoods and economic opportunities. ${ }^{225-226}$ Most 
importantly, the political economy of the conflict must be tackled to harness the national and regional development potential of the mineral trade. ${ }^{227-228}$ 


\section{REFERENCES}

1. Thomas Turner, The Congo wars: conflict, myth and reality, (New York: Zed Books, 2007), 44-45.

2. Ch. Didier Gondola, The History of Congo, (Westport, CT: Greenwood Press, 2002), 8.

3. Adam Hochschild, King Leopold's Ghost, (New York: Houghton Mifflin Company, 1999), 10-11.

4. Adam Hochschild, King Leopold's Ghost, (New York: Houghton Mifflin Company, 1999), 27-28, 38, 81-82, 87, 92-93.

5. Ch. Didier Gondola, The History of Congo, (Westport, CT: Greenwood Press, 2002), 68.

6. Ch. Didier Gondola, The History of Congo, (Westport, CT: Greenwood Press, 2002), 115.

7. Ch. Didier Gondola, The History of Congo, (Westport, CT: Greenwood Press, 2002), 4.

8. Ch. Didier Gondola, The History of Congo, (Westport, CT: Greenwood Press, 2002), 117.

9. Ch. Didier Gondola, The History of Congo, (Westport, CT: Greenwood Press, 2002), 5.

10. Ch. Didier Gondola, The History of Congo, (Westport, CT: Greenwood Press, 2002), 131.

11. Ch. Didier Gondola, The History of Congo, (Westport, CT: Greenwood Press, 2002), 147.

12. Ch. Didier Gondola, The History of Congo, (Westport, CT: Greenwood Press, 2002), 154.

13. Ch. Didier Gondola, The History of Congo, (Westport, CT: Greenwood Press, 2002), 159.

14. Ch. Didier Gondola, The History of Congo, (Westport, CT: Greenwood Press, 2002), 167.

15. United Nations Security Council, Report of the Panel of Experts on the Illegal Exploitation of Natural Resources and Other forms of Wealth of the Democratic Republic of the Congo, S/2001/357 (2001), paragraph 32.

16. U.S. Department of State, Background Note: Democratic Republic of the Congo, Available: http://www.state.gov/r/pa/ei/bgn/2823.htm (July 20, 2010).

17. "Eastern Congo peace deal signed," BBC News, Jan. 23, 2008

(http://news.bbc.co.uk/2/hi/africa/7204898.stm).

18. United Nations Security Council, Final Report of the Group of Experts on the Democratic Republic of the Congo, S/2009/603, (2009), paragraph 13.

19. U.S. Department of State, Background Note: Democratic Republic of the Congo, Available: http://www.state.gov/r/pa/ei/bgn/2823.htm (July 20, 2010).

20. U.S. Department of State, Background Note: Democratic Republic of the Congo, Available: http://www.state.gov/r/pa/ei/bgn/2823.htm (July 20, 2010).

21. U.S. Department of State, Background Note: Democratic Republic of the Congo, Available: http://www.state.gov/r/pa/ei/bgn/2823.htm (July 20, 2010).

22. United Nations Security Council, Thirty-first report of the Secretary-General on the United Nations Organization Mission in the Democratic Republic of the Congo, S/2010/164, (2010), paragraph 3.

23. "Kimia II military operation will be completed on 31 December, Doss says," MONUC News, Dec. 17, 2009

(http://monuc.unmissions.org/LinkClick.aspx?fileticket=ZGvw5Cc5rAQ\%3D\&tabid=1267\&mid=3650).

24. United Nations Security Council, Thirty-first report of the Secretary-General on the United Nations Organization Mission in the Democratic Republic of the Congo, S/2010/164, (2010), paragraph 20.

25. U.S. Department of State, Background Note: Democratic Republic of the Congo, Available: http://www.state.gov/r/pa/ei/bgn/2823.htm (July 20, 2010).

26. United Nations Security Council, Thirty-first report of the Secretary-General on the United Nations Organization Mission in the Democratic Republic of the Congo, S/2010/164, (2010), page 3.

27. United Nations Security Council, Thirty-first report of the Secretary-General on the United Nations Organization Mission in the Democratic Republic of the Congo, S/2010/164, (2010), paragraph 23.

28. United Nations Security Council, Thirty-first report of the Secretary-General on the United Nations Organization Mission in the Democratic Republic of the Congo, S/2010/164, (2010), paragraph 35.

29. United Nations Security Council, Thirty-first report of the Secretary-General on the United Nations Organization Mission in the Democratic Republic of the Congo, S/2010/164, (2010), paragraph 84. 
30. United Nations Security Council, Thirty-first report of the Secretary-General on the United Nations Organization Mission in the Democratic Republic of the Congo, S/2010/164, (2010), paragraph 90.

31. United Nations Security Council, Thirty-first report of the Secretary-General on the United Nations Organization Mission in the Democratic Republic of the Congo, S/2010/164, (2010), paragraphs 124 \& 164.

32. United Nations Security Council, Thirty-first report of the Secretary-General on the United Nations Organization Mission in the Democratic Republic of the Congo, S/2010/164, (2010), paragraph 12.

33. United Nations Security Council, Thirty-first report of the Secretary-General on the United Nations Organization Mission in the Democratic Republic of the Congo, S/2010/164, (2010), paragraph 44.

34. United Nations Security Council, Thirty-first report of the Secretary-General on the United Nations Organization Mission in the Democratic Republic of the Congo, S/2010/164, (2010), paragraph 13.

35. U.S. Department of State, Background Note: Democratic Republic of the Congo, Available: http://www.state.gov/r/pa/ei/bgn/2823.htm (July 20, 2010).

36. "Analysis: Fighting for peace in the Kivus," IRIN, Feb. 22, 2010. (http://www.irinnews.org/Report.aspx?ReportId=88193)

37. Coghlan, B., Ngoy, P., Mulumba, F., Hardy, C., Bemo, V.N., Stewart, T., Lewis, J. and Brennan, R. (2007), "Mortality in the Democratic Republic of Congo: An Ongoing Crisis,"

(http://www.theirc.org/sites/default/files/resource-file/2006-7_congoMortalitySurvey.pdf).

38. United Nations General Assembly, Human Rights Council, Technical Assistance and Capacity Building, Second joint report of seven United Nations experts on the situation in the Democratic Republic of the Congo, A/HRC/13/63, (2010), paragraph 27.

39. MONUC, Briefing Materials, Oct. 22, 2009, http://monuc.unmissions.org/LinkClick.aspx?fileticket=AlUP9TdBzG4=\&tabid=2615\&mid=3120.

40. UNHCR, Reproductive Health in Refugee Situations. An Interagency Field Manual (Geneva: UNHCR, 1999).

41. United Nations General Assembly, Human Rights Council, Technical Assistance and Capacity Building, Second joint report of seven United Nations experts on the situation in the Democratic Republic of the Congo, A/HRC/13/63, (2010), paragraph 24.

42. "Analysis: Fighting for peace in the Kivus," IRIN, Feb. 22, 2010. (http://www.irinnews.org/Report.aspx?ReportId=88193)

43. "Analysis: Fighting for peace in the Kivus," IRIN, Feb. 22, 2010. (http://www.irinnews.org/Report.aspx?ReportId=88193)

44. “Massive refugee influx from DR Congo straining neighbours' resources-UN", UN New Centre, Jan. 12, 2010, (http://www.un.org/apps/news/story.asp?NewsID=33461).

45. AAAS Science and Human Rights Program, Evidence of Destruction in the Democratic Republic of Congo, March 19, 2010, http://shr.aaas.org/geotech/drcongo/drcongo.shtml.

46. Human Rights Watch, "DR Congo: Civilian Cost of Military Operation is Unacceptable," Oct. 13, 2009, http://www.hrw.org/en/news/2009/10/12/dr-congo-civilian-cost-military-operation-unacceptable.

47. Paul Collier, Economic Causes of Civil Conflict, Global Policy Forum, http://www.globalpolicy.org/component/content/article/182/33884.html (June 15, 2000).

48. Zahra Moloo, The Democratic Republic of the Congo's Economic War: Investigating the Origin of Anonymous Commodities in the Global Capitalist System, Ota Benga Alliance, http://www.otabenga.org/node/91 (Oct. 10, 2007).

49. Michael Nest, The Democratic Republic of Congo: Economic Dimensions of War and Peace, (Boulder, Colorado, 2006), 31.

50. United Nations Security Council, Report of the Panel of Experts on the Illegal Exploitation of Natural Resources and Other forms of Wealth of the Democratic Republic of the Congo, S/2001/357 (2001), paragraph 27.

51. Collier, Paul, Anke Hoeffler, and Dominic Rohner, "Beyond Greed and Grievance, Feasibility and Civil War," Centre for the Study of African Economics Working Paper Series (CSAE WPS/2006-10), (2006), http://www.csae.ox.ac.uk/workingpapers/pdfs/2006-10text.pdf. 
52. Ken Anderson, Imperial Clash on the Congo Resource Front, The Public Record. (December 16, 2008), http://pubrecord.org/nation/462/imperial-clash-on-the-congo-resource-front/.

53. Thomas Turner, The Congo wars: conflict, myth and reality, (New York: Zed Books, 2007), 12-13.

54. Collier, Paul, Anke Hoeffler, and Dominic Rohner, "Beyond Greed and Grievance, Feasibility and Civil War," Centre for the Study of African Economics Working Paper Series (CSAE WPS/2006-10), (2006), http://www.csae.ox.ac.uk/workingpapers/pdfs/2006-10text.pdf.

55. Collier, Paul, Anke Hoeffler, and Dominic Rohner, "Beyond Greed and Grievance, Feasibility and Civil War," Centre for the Study of African Economics Working Paper Series (CSAE WPS/2006-10), (2006), http://www.csae.ox.ac.uk/workingpapers/pdfs/2006-10text.pdf.

56. Collier, Paul, Anke Hoeffler, and Dominic Rohner, "Beyond Greed and Grievance, Feasibility and Civil War," Centre for the Study of African Economics Working Paper Series (CSAE WPS/2006-10), (2006), http://www.csae.ox.ac.uk/workingpapers/pdfs/2006-10text.pdf.

57. Collier, Paul, Anke Hoeffler, and Dominic Rohner, "Beyond Greed and Grievance, Feasibility and Civil War," Centre for the Study of African Economics Working Paper Series (CSAE WPS/2006-10), (2006), http://www.csae.ox.ac.uk/workingpapers/pdfs/2006-10text.pdf.

58. Spittaels, S. and Hilgert, F., Mapping Conflict Motives: Eastern DRC, International Peace Information Service, (March 4, 2008), http://www.ipisresearch.be/maps/Oost-

Congo/20080506_Mapping_Eastern_DRC.pdf.

59. Spittaels, S. and Hilgert, F., Mapping Conflict Motives: Eastern DRC, International Peace Information Service, (March 4, 2008), http://www.ipisresearch.be/maps/Oost-

Congo/20080506_Mapping_Eastern_DRC.pdf.

60. Spittaels, S. and Hilgert, F., Mapping Conflict Motives: Eastern DRC, International Peace Information Service, (March 4, 2008), http://www.ipisresearch.be/maps/Oost-

Congo/20080506_Mapping_Eastern_DRC.pdf.

61. Human Rights Watch, Renewed Crisis in North Kivu, (October 23, 2007), http://www.hrw.org/en/reports/2007/10/22/renewed-crisis-north-kivu.

62. Ken Anderson, Imperial Clash on the Congo Resource Front, The Public Record. (December 16, 2008), http://pubrecord.org/nation/462/imperial-clash-on-the-congo-resource-front/.

63. Ken Anderson, Imperial Clash on the Congo Resource Front, The Public Record. (December 16, 2008), http://pubrecord.org/nation/462/imperial-clash-on-the-congo-resource-front/.

64. Collier, Paul, and Anke Hoeffler, "On Economic Causes of Civil War," Oxford Economic Papers, 50 (1998): 563-573.

65. Collier, Paul, and Anke Hoeffler, "Greed and Grievance in Civil War," Oxford Economic Papers, 56 (2004): 563-595.

66. Collier, Paul, Anke Hoeffler, and Dominic Rohner, "Beyond Greed and Grievance, Feasibility and Civil War," Centre for the Study of African Economics Working Paper Series (CSAE WPS/2006-10), (2006), http://www.csae.ox.ac.uk/workingpapers/pdfs/2006-10text.pdf.

67. Paul Collier, Economic Causes of Civil Conflict, Global Policy Forum, http://www.globalpolicy.org/component/content/article/182/33884.html (June 15, 2000).

68. Global Witness, “Faced with a gun, what can you do?”, (July 21, 2009), http://www.globalwitness.org/media_library_detail.php/786/en/global_witness_report_faced_with_a_gun _what_can_yo.

69. United Nations Security Council, Final Report of the Group of Experts on the Democratic Republic of the Congo, S/2008/773, (2008), paragraphs 73 and 77.

70. Paul Collier, Economic Causes of Civil Conflict, Global Policy Forum, http://www.globalpolicy.org/component/content/article/182/33884.html (June 15, 2000).

71. Collier, Paul, Anke Hoeffler, and Dominic Rohner, "Beyond Greed and Grievance, Feasibility and Civil War," Centre for the Study of African Economics Working Paper Series (CSAE WPS/2006-10), (2006), http://www.csae.ox.ac.uk/workingpapers/pdfs/2006-10text.pdf.

72. Philippe Le Billon, "The political ecology of war: natural resources and armed conflicts," Political Geography, 20 (2001): 561-584. 
73. Collier, Paul, Anke Hoeffler, and Dominic Rohner, "Beyond Greed and Grievance, Feasibility and Civil War," Centre for the Study of African Economics Working Paper Series (CSAE WPS/2006-10), (2006), http://www.csae.ox.ac.uk/workingpapers/pdfs/2006-10text.pdf.

74. Collier, Paul, Anke Hoeffler, and Dominic Rohner, "Beyond Greed and Grievance, Feasibility and Civil War," Centre for the Study of African Economics Working Paper Series (CSAE WPS/2006-10), (2006), http://www.csae.ox.ac.uk/workingpapers/pdfs/2006-10text.pdf.

75. Collier, Paul, and Anke Hoeffler, "On Economic Causes of Civil War," Oxford Economic Papers, 50 (1998): 563-573.

76. Collier, Paul, and Anke Hoeffler, "Greed and Grievance in Civil War," Oxford Economic Papers, 56 (2004): 563-595.

77. Fearon, James and David Laitin, "Ethnicity, Insurgency, and Civil War,” American Political Science Review, 97 (2003): 75-90.

78. World Bank, World Development Indicators (Washington, DC: World Bank, 2010), http://data.worldbank.org/indicator.

79. U.S. Department of State, Background Note: Democratic Republic of the Congo, Available: http://www.state.gov/r/pa/ei/bgn/2823.htm (July 20, 2010).

80. Fearon, James and David Laitin, "Ethnicity, Insurgency, and Civil War," American Political Science Review, 97 (2003): 75-90.

81. Collier, Paul, Anke Hoeffler, and Dominic Rohner, "Beyond Greed and Grievance, Feasibility and Civil War," Centre for the Study of African Economics Working Paper Series (CSAE WPS/2006-10), (2006), http://www.csae.ox.ac.uk/workingpapers/pdfs/2006-10text.pdf.

82. Enough Project, Roots of the Crisis-Congo, (2009), http://www.enoughproject.org/conflict_areas/eastern_congo/roots-crisis.

83. Miguel, Edward, Satyanath Shanker and Ernest Sergenti, "Economic Shocks and Civil Conflict: An Instrumental Variables Approach," Journal of Political Economy, 112 (2004): 725-53.

84. World Development Indicators, http://data.worldbank.org/indicator.

85. Collier, Paul, Anke Hoeffler, and Dominic Rohner, "Beyond Greed and Grievance, Feasibility and Civil War," Centre for the Study of African Economics Working Paper Series (CSAE WPS/2006-10), (2006), http://www.csae.ox.ac.uk/workingpapers/pdfs/2006-10text.pdf.

86. Lujala, P., N.P. Gleditsch and E. Gilmore, "A diamond curse? Civil war and a lootable resource," Journal of Conflict Resolution, 49 (2005): 538-562.

87. Ken Anderson, Imperial Clash on the Congo Resource Front, The Public Record. (December 16, 2008), http://pubrecord.org/nation/462/imperial-clash-on-the-congo-resource-front/.

88. United Nations Security Council, Final Report of the Group of Experts on the Democratic Republic of the Congo, S/2009/603, (2009), 3.

89. Collier, Paul, Anke Hoeffler, and Dominic Rohner, "Beyond Greed and Grievance, Feasibility and Civil War," Centre for the Study of African Economics Working Paper Series (CSAE WPS/2006-10), (2006), http://www.csae.ox.ac.uk/workingpapers/pdfs/2006-10text.pdf.

90. Collier, Paul, Anke Hoeffler and Dominic Rohner, "Beyond greed and grievance: feasibility and civil war," Oxford Economic Papers, 61 (2008): 1-27.

91. Serge Michailof, La Grance et L'Afrique: vade-mecum pour un nouveau voyage (Paris, Karthala, 1993).

92. Serge Michailof, "Côte d'Ivoire 2005: bienvenue sur le Titanic!”, Commentaire, 28 (2005): 393-404.

93. The Library of Congress, A Country Study: Zaire (Former), http://lcweb2.loc.gov/frd/cs/zrtoc.html (July 23, 2010).

94. Collier, Paul, Anke Hoeffler, and Dominic Rohner, "Beyond Greed and Grievance, Feasibility and Civil War," Centre for the Study of African Economics Working Paper Series (CSAE WPS/2006-10), (2006), http://www.csae.ox.ac.uk/workingpapers/pdfs/2006-10text.pdf.

95. United Nations Security Council, Final Report of the Group of Experts on the Democratic Republic of the Congo, S/2009/603, (2009), paragraph 315.

96. Paul Collier, Economic Causes of Civil Conflict, Global Policy Forum, http://www.globalpolicy.org/component/content/article/182/33884.html (June 15, 2000). 
97. Collier, Paul, Anke Hoeffler, and Dominic Rohner, "Beyond Greed and Grievance, Feasibility and Civil War," Centre for the Study of African Economics Working Paper Series (CSAE WPS/2006-10), (2006), http://www.csae.ox.ac.uk/workingpapers/pdfs/2006-10text.pdf.

98. Michael Ross, "What Do We Know about Natural Resources and Civil War?", Journal of Peace Research, 41 (2004): 337-356.

99. Le Billon, Philippe, "The political ecology of war: natural resources and armed conflicts," Political Geography, 20 (2001): 561-584.

100. Le Billon, Philippe, "The political ecology of war: natural resources and armed conflicts," Political Geography, 20 (2001): 561-584.

101. Le Billon, Philippe, "The political ecology of war: natural resources and armed conflicts," Political Geography, 20 (2001): 561-584.

102. Le Billon, Philippe, "The political ecology of war: natural resources and armed conflicts," Political Geography, 20 (2001): 561-584.

103. Le Billon, Philippe, "The political ecology of war: natural resources and armed conflicts," Political Geography, 20 (2001): 561-584.

104. Le Billon, Philippe, "The political ecology of war: natural resources and armed conflicts," Political Geography, 20 (2001): 561-584.

105. Le Billon, Philippe, "The political ecology of war: natural resources and armed conflicts," Political Geography, 20 (2001): 561-584.

106. Paul Collier, Economic Causes of Civil Conflict, Global Policy Forum, http://www.globalpolicy.org/component/content/article/182/33884.html (June 15, 2000).

107. J. Fairhead, "The conflict over natural and environmental resources: In: E.E. Wayne, F. Stewart \& R. Vayrynen, The origins of humanitarian emergencies: war and displacement in developing countries (Oxford: Oxford University Press, 2000).

108. Philippe Le Billon, "Nature factionalism, and political power in Cambodia, Paper presented at the Inaugural Critical Geography Conference, (Vancouver), 1997.

109. Le Billon, Philippe, "The political ecology of war: natural resources and armed conflicts," Political Geography, 20 (2001): 561-584.

110. Adam Hochschild, King Leopold's Ghost, (New York: Houghton Mifflin Company, 1999).

111. J.C. Miller, Way of death: merchant capitalism and the Angolan slave trade, 1730-1830 (Madison, WI: University of Wisconsin Press, 1988).

112. F. Misser, and O. Vallée, Les Gemmocraties. L'Economie Politique du Deamant Africain, (Paris: Desclée De Brouwer, 1997).

113. Le Billon, Philippe, "The political ecology of war: natural resources and armed conflicts," Political Geography, 20 (2001): 561-584.

114. United Nations Security Council, Statement by the President of the Security Council, S/PRST/2000/20, (June 2, 2000).

115. United Nations Security Council, Final Report of the Group of Experts on the Democratic Republic of the Congo, S/2008/773, (2008), paragraphs 72-77.

116. United Nations Security Council, Final Report of the Group of Experts on the Democratic Republic of the Congo, S/2008/773, (2008), paragraphs 57, 61-68.

117. United Nations Security Council, Final Report of the Group of Experts on the Democratic Republic of the Congo, S/2009/603, (2009), paragraph 23.

118. United Nations Security Council, Final Report of the Group of Experts on the Democratic Republic of the Congo, S/2009/603, (2009), paragraphs 345, 357, 371-374.

119. United Nations General Assembly, Human Rights Council, Technical Assistance and Capacity Building, Second joint report of seven United Nations experts on the situation in the Democratic Republic of the Congo, A/HRC/13/63, (2010), p.8.

120. United Nations General Assembly, Human Rights Council, Technical Assistance and Capacity Building, Second joint report of seven United Nations experts on the situation in the Democratic Republic of the Congo, A/HRC/13/63, (2010), paragraph 78. 
121. United Nations General Assembly, Human Rights Council, Technical Assistance and Capacity Building, Second joint report of seven United Nations experts on the situation in the Democratic Republic of the Congo, A/HRC/13/63, (2010), paragraph 79.

122. United National Security Council, Report of the Panel of Experts on the Illegal Exploitation of Natural Resources and other Forms of Wealth of the Democratic Republic of the Congo, S/2001/357, (April 12, 2001).

123. United Nations Security Council, Final Report of the Group of Experts on the Democratic Republic of the Congo, S/2008/773, (2008), paragraph 77.

124. "How smuggling pays for killing," Africa Confidential, 49 (Nov. 14, 2008), http://www.africaconfidential.com/article-preview/id/2867/No-Title.

125. "How smuggling pays for killing," Africa Confidential, 49 (Nov. 14, 2008), http://www.africaconfidential.com/article-preview/id/2867/No-Title.

126. Global Witness, Control of mines by warring parties threatens peace efforts in eastern Congo, (Sept. 10, 2008) http://www.globalwitness.org/media_library_detail.php/663/en/control_of_mines.

127. United Nations General Assembly, Human Rights Council, Technical Assistance and Capacity Building, Second joint report of seven United Nations experts on the situation in the Democratic Republic of the Congo, A/HRC/13/63, (2010), paragraph 70.

128. Enough Project, A Comprehensive Approach to Congo's Conflict Minerals, (April 2009), http://www.enoughproject.org/publications/comprehensive-approach-conflict-minerals-strategy-paper.

129. United Nations Security Council, Final Report of the Group of Experts on the Democratic Republic of the Congo, S/2009/603, (2009), paragraph 299.

130. MONUC News, "Kimia II military operation will be completed on 31 December, Doss says," (Dec. 17, 2009), http://monuc.unmissions.org/LinkClick.aspx?fileticket=ZGvw5Cc5rAQ\%3D\&tabid=1267\&mid=3650.

131. United Nations Security Council, Final Report of the Group of Experts on the Democratic Republic of the Congo, S/2009/603, (2009), paragraph 299.

132. Daniel Magnowski, “Tin price spike shows Congo's growing origin role," Reuters, Oct. 30, 2008, (http://www.reuters.com/article/latestCrisis/idUSLU661455).

133. Enough Project, A Comprehensive Approach to Congo's Conflict Minerals, (April 2009), http://www.enoughproject.org/publications/comprehensive-approach-conflict-minerals-strategy-paper.

134. International Tin Research Institute, "Review ITRI Reports New Data On Global Tin Use and Recycling," Dec. 18, 2008, http://www.itri.co.uk/pooled/articles/BF_NEWSART/view.asp?Q=BF_NEWS-ART_308811.

135. Talison Minerals, “Talison to Suspend Wodgina Tantalum Operations," Press Statement, Nov. 26, 2008, (http://www.talisontantalum.com/pdfs/Media_Release_26_Nov_08_FINAL.pdf).

136. Enough Project, A Comprehensive Approach to Congo's Conflict Minerals, (April 2009), http://www.enoughproject.org/publications/comprehensive-approach-conflict-minerals-strategy-paper.

137. Global Witness, “Faced with a gun, what can you do?”, (July 21, 2009), http://www.globalwitness.org/media_library_detail.php/786/en/global_witness_report_faced_with_a_gun _what_can_yo.

138. Enough Project, A Comprehensive Approach to Congo's Conflict Minerals, (April 2009), http://www.enoughproject.org/publications/comprehensive-approach-conflict-minerals-strategy-paper.

139. U.S. Geological Survey, Mineral Commodity Survey for Tungsten, Jan. 2009, http://minerals.usgs.gov/minerals/pubs/commodity/tungsten/.

140. International Tungsten Industry Association Newsletter, Dec. 2007.

141. United Nations Security Council, Final Report of the Group of Experts on the Democratic Republic of the Congo, S/2009/603, (2009), paragraph 299.

142. Global Witness, “Faced with a gun, what can you do?”, (July 21, 2009), http://www.globalwitness.org/media_library_detail.php/786/en/global_witness_report_faced_with_a_gun _what_can_yo. 
143. Enough Project, A Comprehensive Approach to Congo's Conflict Minerals, (April 2009), http://www.enoughproject.org/publications/comprehensive-approach-conflict-minerals-strategy-paper.

144. United Nations Security Council, Final Report of the Group of Experts on the Democratic Republic of the Congo, S/2009/603, (2009), paragraph 124.

145. United Nations Security Council, Final Report of the Group of Experts on the Democratic Republic of the Congo, S/2009/603, (2009), paragraph 124.

146. Enough Project, A Comprehensive Approach to Congo's Conflict Minerals, (April 2009), http://www.enoughproject.org/publications/comprehensive-approach-conflict-minerals-strategy-paper.

147. Global Witness, “Faced with a gun, what can you do?”, (July 21, 2009), http://www.globalwitness.org/media_library_detail.php/786/en/global_witness report faced_with_a_gun _what_can_yo.

148. John Prendergast and Sasha Lezhev, From Mine to Mobile Phone, The Conflict Minerals Supply Chain, The Enough Project, (Nov. 10, 2009), http://www.enoughproject.org/publications/mine-mobile-phone.

149. Enough Project, A Comprehensive Approach to Congo's Conflict Minerals, (April 2009), http://www.enoughproject.org/publications/comprehensive-approach-conflict-minerals-strategy-paper.

150. John Prendergast and Sasha Lezhev, From Mine to Mobile Phone, The Conflict Minerals Supply Chain, (Nov. 10, 2009), http://www.enoughproject.org/publications/mine-mobile-phone.

151. United Nations Security Council, Final Report of the Group of Experts on the Democratic Republic of the Congo, S/2009/603, (2009), paragraph 200.

152. Human Rights Watch, You Will Be Punished: Attacks on Civilians in Eastern Congo, (Dec. 13, 2009), http://www.hrw.org/node/87151.

153. Global Witness, “Faced with a gun, what can you do?”, (July 21, 2009), http://www.globalwitness.org/media_library_detail.php/786/en/global_witness_report_faced_with_a_gun what can yo.

154. Global Witness, "Faced with a gun, what can you do?”, (July 21, 2009), http://www.globalwitness.org/media_library_detail.php/786/en/global_witness_report_faced_with_a_gun _what_can_yo.

155. Global Witness, "Faced with a gun, what can you do?”, (July 21, 2009), http://www.globalwitness.org/media library_detail.php/786/en/global witness report faced_with a gun _what_can_yo.

156. Global Witness, “Faced with a gun, what can you do?”, (July 21, 2009), http://www.globalwitness.org/media_library_detail.php/786/en/global_witness_report_faced_with_a_gun _what_can_yo.

157. Global Witness, “Faced with a gun, what can you do?”, (July 21, 2009),

http://www.globalwitness.org/media_library_detail.php/786/en/global_witness_report_faced_with_a_gun _what_can_yo.

158. John Prendergast and Sasha Lezhev, From Mine to Mobile Phone, The Conflict Minerals Supply Chain, The Enough Project, (Nov. 10, 2009), http://www.enoughproject.org/publications/mine-mobile-phone.

159. Global Witness, “Faced with a gun, what can you do?”, (July 21, 2009), http://www.globalwitness.org/media_library_detail.php/786/en/global_witness_report_faced_with_a_gun _what_can_yo.

160. Global Witness, “Faced with a gun, what can you do?”, (July 21, 2009), http://www.globalwitness.org/media library detail.php/786/en/global witness report faced with a gun _what_can_yo.

161. Global Witness, “Faced with a gun, what can you do?”, (July 21, 2009), http://www.globalwitness.org/media_library_detail.php/786/en/global_witness_report_faced_with_a_gun what can yo.

162. David Sullivan and Noel Atama, Digging In, Recent Developments on Conflict Minerals, The Enough Project, (Jan. 2010), http://www.enoughproject.org/files/publications/DiggingInConflictMinerals.pdf.

163. John Prendergast and Sasha Lezhev, From Mine to Mobile Phone, The Conflict Minerals Supply Chain, The Enough Project, (Nov. 10, 2009), http://www.enoughproject.org/publications/mine-mobile-phone. 
164. John Prendergast and Sasha Lezhev, From Mine to Mobile Phone, The Conflict Minerals Supply Chain, The Enough Project, (Nov. 10, 2009), http://www.enoughproject.org/publications/mine-mobile-phone.

165. Global Witness, “Faced with a gun, what can you do?”, (July 21, 2009), http://www.globalwitness.org/media_library_detail.php/786/en/global_witness_report_faced_with_a_gun _what_can_yo.

166. John Prendergast and Sasha Lezhev, From Mine to Mobile Phone, The Conflict Minerals Supply Chain, The Enough Project, (Nov. 10, 2009), http://www.enoughproject.org/publications/mine-mobile-phone.

167. Enough Project, A Comprehensive Approach to Congo's Conflict Minerals, (April 2009), http://www.enoughproject.org/publications/comprehensive-approach-conflict-minerals-strategy-paper.

168. John Prendergast and Sasha Lezhev, From Mine to Mobile Phone, The Conflict Minerals Supply Chain, The Enough Project, (Nov. 10, 2009), http://www.enoughproject.org/publications/mine-mobile-phone.

169. Global Witness, “Faced with a gun, what can you do?”, (July 21, 2009), http://www.globalwitness.org/media_library_detail.php/786/en/global_witness_report_faced_with_a_gun _what_can_yo.

170. "Réflexion de la Fédération des Entreprises du Congo sur l'exploitation des minerais au Kivu: ses impacts sur la situation socio économiqe et la recherché commune des pistes de solutions durables." Bukavu, Aug. 24, 2008.

171. John Prendergast and Sasha Lezhev, From Mine to Mobile Phone, The Conflict Minerals Supply Chain, The Enough Project, (Nov. 10, 2009), http://www.enoughproject.org/publications/mine-mobile-phone.

172. United Nations Security Council, Final Report of the Group of Experts on the Democratic Republic of the Congo, S/2008/773, (2008), paragraphs 59-59, 74-78, 83 and 88.

173. United Nations Security Council, Final Report of the Group of Experts on the Democratic Republic of the Congo, S/2009/603, (2009), paragraphs 165-167, 208, 230 and 307.

174. Global Witness, “Faced with a gun, what can you do?”, (July 21, 2009),

http://www.globalwitness.org/media_library_detail.php/786/en/global_witness_report_faced_with_a_gun _what_can_yo.

175. Global Witness, "Faced with a gun, what can you do?”, (July 21, 2009), http://www.globalwitness.org/media_library_detail.php/786/en/global_witness_report_faced_with_a_gun what can yo.

176. United Nations Security Council, Final Report of the Group of Experts on the Democratic Republic of the Congo, S/2009/603, (2009), paragraph 230.

177. United Nations Security Council, Final Report of the Group of Experts on the Democratic Republic of the Congo, S/2008/773, (2008), paragraphs 57-60.

178. United Nations Security Council, Final Report of the Group of Experts on the Democratic Republic of the Congo, S/2008/773, (2008), paragraph 78.

179. United Nations Security Council, Final Report of the Group of Experts on the Democratic Republic of the Congo, S/2009/603, (2009), paragraphs 165 and 168.

180. United Nations Security Council, Final Report of the Group of Experts on the Democratic Republic of the Congo, S/2009/603, (2009), paragraph 145.

181. United Nations Security Council, Final Report of the Group of Experts on the Democratic Republic of the Congo, S/2009/603, (2009), paragraph 166 and 171.

182. United Nations Security Council, Final Report of the Group of Experts on the Democratic Republic of the Congo, S/2009/603, (2009), paragraph 166.

183. United Nations Security Council, Final Report of the Group of Experts on the Democratic Republic of the Congo, S/2009/603, (2009), paragraph 127.

184. United Nations Security Council, Final Report of the Group of Experts on the Democratic Republic of the Congo, S/2009/603, (2009), paragraphs 128-130.

185. United Nations Security Council, Final Report of the Group of Experts on the Democratic Republic of the Congo, S/2009/603, (2009), paragraph 133.

186. United Nations Security Council, Final Report of the Group of Experts on the Democratic Republic of the Congo, S/2009/603, (2009), paragraph 177. 
187. "Uganda Ministry of Energy and Minerals, Annual Report for 2007".

188. John Prendergast and Sasha Lezhev, From Mine to Mobile Phone, The Conflict Minerals Supply Chain, The Enough Project, (Nov. 10, 2009), http://www.enoughproject.org/publications/mine-mobile-phone.

189. Global Witness, “Faced with a gun, what can you do?”, (July 21, 2009), http://www.globalwitness.org/media_library_detail.php/786/en/global_witness_report_faced_with_a_gun what can yo.

190. Global Witness, “Faced with a gun, what can you do?”, (July 21, 2009), http://www.globalwitness.org/media_library_detail.php/786/en/global_witness_report_faced_with_a_gun _what_can_yo.

191. Rwanda Investment and Export Promotion Agency, The Wealth of the Land: Rwanda Minerals, Invest in Rwanda; A New Frontier of Opportunity, (2008), 44.

192. Rwanda Investment and Export Promotion Agency, The Wealth of the Land: Rwanda Minerals, Invest in Rwanda; A New Frontier of Opportunity, (2008), 44.

193. United Nations Security Council, Final Report of the Group of Experts on the Democratic Republic of the Congo, S/2008/773, (2008), paragraphs 90-93.

194. United Nations Security Council, Final Report of the Group of Experts on the Democratic Republic of the Congo, S/2009/603, (2009), paragraphs 142, 149, 152.

195. Division des Mines Nord-Kivu and Division des Mines Sud-Kivu, Rapport Annuel 2007.

196. Global Witness, “Faced with a gun, what can you do?”, (July 21, 2009),

http://www.globalwitness.org/media_library_detail.php/786/en/global_witness_report_faced_with_a_gun _what_can_yo.

197. International Tin Research Institute, “Top tin producing companies_-2009," http://www.itri.co.uk/pooled/articles/BF_TECHART/view.asp?Q=BF_TECHART_285697.

198. Global Witness, “Faced with a gun, what can you do?”, (July 21, 2009),

http://www.globalwitness.org/media_library_detail.php/786/en/global_witness_report_faced_with_a_gun _what_can_yo.

199. United Nations Security Council, Final Report of the Group of Experts on the Democratic Republic of the Congo, S/2009/603, (2009), paragraph 165.

200. Division des Mines Nord-Kivu and Division des Mines Sud-Kivu, Rapport Annuel 2007.

201. David Sullivan and Noel Atama, Digging In, Recent Developments on Conflict Minerals, The Enough Project, (Jan. 2010), http://www.enoughproject.org/files/publications/DiggingInConflictMinerals.pdf.

202. United Nations Security Council, Final Report of the Group of Experts on the Democratic Republic of the Congo, S/2009/603, (2009), paragraph 178.

203. United Nations Security Council, Final Report of the Group of Experts on the Democratic Republic of the Congo, S/2008/773, (2008), paragraph 88.

204. Joe Bavier, "Thiasarco suspends Congo tin ore purchases," Reuters Africa, Sept. 18, 2009 (http://af.reuters.com/article/investingNews/idAFJOE58H09S20090918).

205. Franz Wild, "Congo Asks Amalgamated, Traxys to Resume Tin Orders (Update 1)," Bloomberg, Oct. 9, 2009 (http://www.bloomberg.com/apps/news?pid=newsarchive\&sid=auCIoOvBQkrg).

206. John Prendergast and Sasha Lezhev, From Mine to Mobile Phone, The Conflict Minerals Supply Chain, The Enough Project, (Nov. 10, 2009), http://www.enoughproject.org/publications/mine-mobile-phone.

207. John Prendergast and Sasha Lezhev, From Mine to Mobile Phone, The Conflict Minerals Supply Chain, The Enough Project, (Nov. 10, 2009), http://www.enoughproject.org/publications/mine-mobile-phone.

208. Brooke Smith "Hello I'm a Mac, and Here's How I Help Fuel the World's Deadliest Conflict," The Huffington Post, (June 28, 2010) http://www.huffingtonpost.com/brooke-smith/hello-im-a-mac-andheres_b_617256.html.

209. Nicholas D. Kristoff, "Death by Gadget," The New York Times (June 26, 2010) http://www.nytimes.com/2010/06/27/opinion/27kristof.html?_r=1\&ref=nicholasdkristof.

210. Brooke Smith "Hello I'm a Mac, and Here's How I Help Fuel the World's Deadliest Conflict," The Huffington Post, http://www.huffingtonpost.com/brooke-smith/hello-im-a-mac-andheres_b_617256.html. 
211. YouTube, "I'm a Mac...and I've Got a Dirty Secret," http://www.youtube.com/watch?v=5Ycih jMObQ (July 28, 2010).

212. Brian X. Chen, "In E-Mail, Steve Jobs Comments on iPhone4 Minerals," Wired Gadget Lab, (June 28, 2010) http://www.wired.com/gadgetlab/2010/06/steve-jobs-iphone4/.

213. Ch. Didier Gondola, The History of Congo, (Westport, CT: Greenwood Press, 2002), 6.

214. Ch. Didier Gondola, The History of Congo, (Westport, CT: Greenwood Press, 2002), 178.

215. Ch. Didier Gondola, The History of Congo, (Westport, CT: Greenwood Press, 2002), 6.

216. Thomas Turner, The Congo wars: conflict, myth and reality, (New York: Zed Books, 2007), 24.

217. H. Sunman and N. Bates, Trading for Peace, U.K. Department of International Development (DFID), (2007) http://webarchive.nationalarchives.gov.uk/+/http://www.dfid.gov.uk/mdg/aid/trading-forpeace.asp

218. Nicholas Garrett and Harrison Mitchell, Trading Conflict for Development, Resource Consulting Services, (April 2009)

http://www.resourceglobal.co.uk/index.php?option=com_docman\&task=cat_view\&gid=34\&Itemid=41.

219. International Tin Research Institute, ITRI Tin Supply Chain Initiative, iTSCi, (October 2009), http://www.itri.co.uk/SITE/UPLOAD/Document/iTSCi_Final_Version_2_English_2.10.09.pdf.

220. Nicholas Garrett and Harrison Mitchell, Trading Conflict for Development, Resource Consulting Services, (April 2009)

http://www.resourceglobal.co.uk/index.php?option=com_docman\&task=cat_view\&gid=34\&Itemid=41.

221. Global Witness, “Faced with a gun, what can you do?”, (July 21, 2009),

http://www.globalwitness.org/media_library_detail.php/786/en/global_witness_report_faced_with_a_gun _what_can_yo.

222. Enough Project, A Comprehensive Approach to Congo's Conflict Minerals, (April 2009), http://www.enoughproject.org/publications/comprehensive-approach-conflict-minerals-strategy-paper.

223. Nicholas Garrett and Harrison Mitchell, Trading Conflict for Development, Resource Consulting Services, (April 2009)

http://www.resourceglobal.co.uk/index.php?option=com_docman\&task=cat_view\&gid=34\&Itemid=41.

224. International Tin Research Institute, ITRI Tin Supply Chain Initiative, iTSCi, (October 2009), http://www.itri.co.uk/SITE/UPLOAD/Document/iTSCi_Final Version_2 English 2.10.09.pdf.

225. Enough Project, A Comprehensive Approach to Congo's Conflict Minerals, (April 2009), http://www.enoughproject.org/publications/comprehensive-approach-conflict-minerals-strategy-paper.

226. Nicholas Garrett and Harrison Mitchell, Trading Conflict for Development, Resource Consulting Services, (April 2009)

http://www.resourceglobal.co.uk/index.php?option=com_docman\&task=cat_view\&gid=34\&Itemid=41.

227. Enough Project, A Comprehensive Approach to Congo's Conflict Minerals, (April 2009), http://www.enoughproject.org/publications/comprehensive-approach-conflict-minerals-strategy-paper.

228. Nicholas Garrett and Harrison Mitchell, Trading Conflict for Development, Resource Consulting Services, (April 2009)

http://www.resourceglobal.co.uk/index.php?option=com_docman\&task=cat_view\&gid=34\&Itemid=41. 


\section{ACKNOWLEDGMENTS}

This paper was produced for the Socio-Cultural Models-Empirical and Evolutionary V\&V Project funded through the Lockheed Martin Co. Shared Vision Program. Thank you to Bob Schlicher, the project principal investigator and my colleague, for his support and encouragement. Thank you to Jack Schryver and Andy Loebl for their feedback during the editing process. 

Appendix A

DEMOCRATIC REPUBLIC OF CONGO FACTS 



\section{Democratic Republic of the Congo Facts}

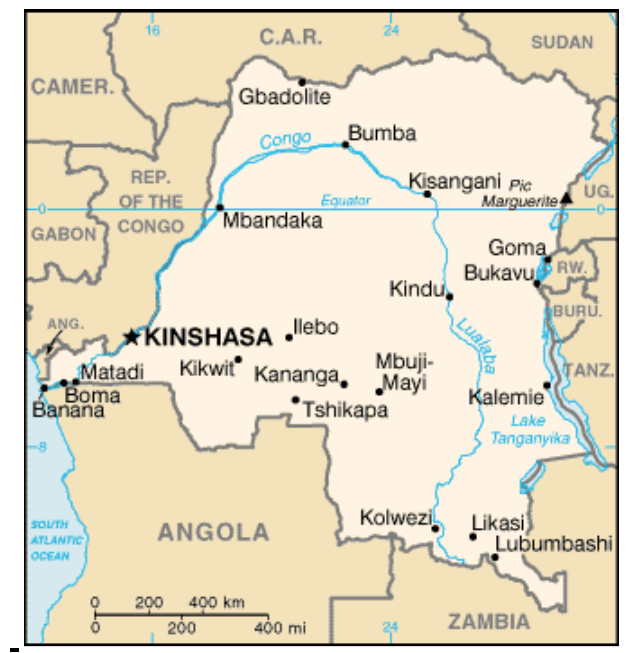

\section{Geography}

\section{Location}

Central Africa

Area

Total: $2,344,858 \mathrm{sq} \mathrm{km}$

Country comparison to the world: 12

Country comparison to Africa: 3

Land: 2,267,048 sq km

Water: $77,810 \mathrm{sq} \mathrm{km}$

\section{Land boundaries}

Total: $10,730 \mathrm{~km}$

Border countries: Angola 2,511 km (of which $225 \mathrm{~km}$ is the boundary of Angola's discontiguous Cabinda Province), Burundi $233 \mathrm{~km}$, Central African Republic $1,577 \mathrm{~km}$, Republic of the Congo 2,410 km, Rwanda $217 \mathrm{~km}$, Sudan $628 \mathrm{~km}$, Tanzania $459 \mathrm{~km}$, Uganda $765 \mathrm{~km}$, Zambia 1,930 km

\section{Coastline:}

$37 m$ with Atlantic Ocean

\section{Elevation extremes:}

Lowest point: Atlantic Ocean $0 \mathrm{~m}$

Highest point: Pic Marguerite on Mont Ngaliema (Mount Stanley) 5,110 m

\section{Natural Resources:}

Cobalt, copper, niobium, tantalum, petroleum, industrial and gem diamonds, gold, silver, zinc, manganese, tin, uranium, coal, hydropower, timber

Source: World Factbook. Washington, DC: Central Intelligence Agency, (2010)

https://www.cia.gov/library/pulications/the-worldfactbook.index.html.

\section{People}

Population

70,916,439 (July 2010 est.)

Country comparison to the world: 18

\section{Ethnic Groups}

Over 200 African ethnic groups of which the majority are Bantu; the four largest tribes - Mongo, Luba, Kongo (all Bantu), and the Mangbetu-Azande (Hamitic) make up about $45 \%$ of the population

\section{Religions}

Roman Catholic 50\%, Protestant 20\%, Kimbanguist $10 \%$, Muslim 10\%, other (includes syncretic sects and indigenous beliefs) $10 \%$

\section{Languages}

French (official), Lingala (a lingua franca trade language), Kingwana (a dialect of Kiswahili or Swahili), Kikongo, Tshiluba

\section{Government}

Government Type

Republic

Capital

Kinshasa

President

Joseph Kabila (since January 17, 2001)

Prime Minister

Adolphe Muzito (since October 10, 2008)

Independence

June 30, 1960 from Belgium

\section{Economy}

GDP (purchasing power parity)

$\$ 21.33$ billion (2009 est.)

$\$ 20.77$ billion (2008 est.)

$\$ 19.56$ billion (2007 est.)

GDP_per capita (PPP)

$\$ 300$ (2009 est.)

$\$ 300$ (2008 est.)

$\$ 300$ (2007 est.) 

Appendix B

MAIN CONFLICT ACTORS 



\section{Main Conflict Actors}

\section{Democratic Forces for the Liberation of Rwanda (FDLR)}

The FDLR is the largest armed group in the Kivus. It is a politico-military movement that originates from ex-FAR soldiers, ex-Interahamwe militiamen and Hutu civilians who fled from Rwanda to the DRC in the aftermath of the genocide in 1994. Many of its current members are too young to have participated in the genocide, but there still exists a powerful core group of Hutus in leadership positions that were involved in the 1994 genocide. The FDLR is spread across North and South $\mathrm{Kivu}$, with a more established presence and greater involvement in mining in South Kivu. Income from mining activities is an important motivating factor for FDLR. FDLR positions are clearly linked to the presence of natural resources. The FDLR has a history of serious human rights violations and its existence has served as a pretext for Rwanda to interfere in the ongoing conflict on Congolese soil. The FDLR claims it wants to create an inter-Rwandan dialogue.

\section{National Congress for the Defense of the People (CNDP)}

The CNDP is a Tutsi-led political movement with a military wing called the Congolese National Army (ANC). Its chairman and military commander, General Laurent Nkunda, was placed under house arrest by Rwanda in 2008. He claims to protect the interests of Rwandophones in Eastern DRC. Bosco Ntaganda, who is indicted by the international Criminal Court (ICC), replaced Nkunda in January 2009 agreeing to steer the group toward peace. However, most observers believe the CNDP has retained its chains of command within the army. In March 2009, the CNDP became a political party and 3,000-4,000 of its fighters joined the Congolese army in the integration process. CNDP controls trade routes by collecting taxes at barriers on the transports of minerals, timber and other goods.

\section{Mai-Mai Groups}

Mai-Mai groups are traditional local defense militias formed on an ad-hoc basis by local leaders who arm young men in villages, often along ethnic lines. Most Mai-Mai groups are known by the name of their leader. Mai-Mai groups have become increasingly involved in the armed conflict over the past ten years. They sometimes fight alongside the Congolese army against the CNDP or other Rwandanbacked groups, and sometimes fight each other.

The main Mai-Mai group is PARECO (Coalition of Patriotic Congolese Resistants), an alliance of several Mayi-Mayi groups loosely allied with the FDLR. PARECO claims it fights to defend the marginalized Congolese people who suffer from the enduring warfare between Nkunda elements and FDLR. PARECO is active in a few mining areas. In January 2009, PARECO followed the CNDP in announcing that it too would cease hostilities and join the ranks of the national army.

\section{Forces Armées de la République Démocratique du Congo (FARDC)}

FARDC is the Congolese national army. North Kivu is under command of the $8^{\text {th }}$ military region and South Kivu is under the command of the $10^{\text {th }}$ military region. The overall strength of FARDC is estimated to be from 130,000-150,000 troops with 60,000 troops are at or close to retirement. The integration of armed groups has resulted in poor loyalty, indiscipline, and disruptions in the chain of command. Integrated Bridages are composed of soldiers with different backgrounds (ex-RCD, exMLC, ex-Mai Mai or government) and come from different regions of the DRC. The army suffers 
from inadequate budget, lack of equipment, lack of pay, and a weak military justice system. FARDC troops have committed numerous human rights violations. FARDC units and commanders from the $8^{\text {th }}$ and $10^{\text {th }}$ military regions are involved in mining in many locations in North and South Kivu.

\section{United Nations Organization Mission in the DRC (MONUC)}

MONUC is the United Nations peace keeping mission in the DRC. MONUC forces deploy and patrol in places where communities are most vulnerable and they protect humanitarian supply lines and camps for the 1.8 million internally displaced persons (IDPS) in eastern Congo. MONUC peacekeepers have also provided logistical support to the Congolese national army in its operations against the FDLR and other armed groups. These efforts, in particular Kimia II, have been criticized because they worsened the humanitarian crisis in North and South Kivu. In July 2010, the mission was renamed to the United Nations Organization Stabilization Mission in the Democratic Republic of the Congo (MONUSCO) as it transforms into a stabilization mission. MONUC is planning to withdraw from DRC in three years. The DRC government wants MONUC to leave the country by September 2011. Troop strength is 20,819 with an additional 4300 civilian personnel. 